\title{
Assessment of Potential Future Hydrogen Markets in the U.S.
}

Ali K. Kastiani

(JPL $-P u b-31,-68$ ) FUTURE HYDBOGEN Propulsion Lab.)

\section{ASSESSMENT OF POTENTIAL MARKETS IN THE U.S. (Jet $65 \mathrm{P} \mathrm{HCAO4/MFAO}$ CSCL $05 \mathrm{C}$}

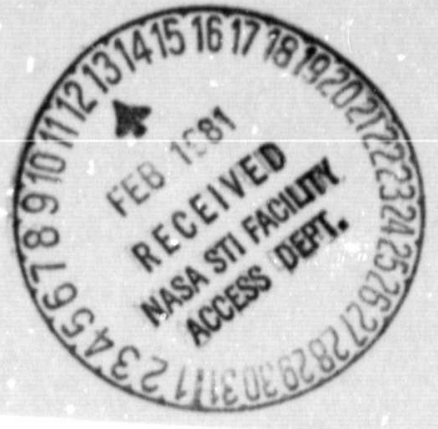

September 1980

Prepared for

International Ēnergy Agency

and

U.S. Department of Energy

Through, an agreement with

National Aeronautics and Space Administration

by

Jet Propulsion Laburatory

California Institute of Technology

Pasadena, Cal : Inia 


\section{Assessment of Potential Future Hydrogen Markets in the U.S.}

Ali K. Kashani

September 1980

Prepared tor

International Energy Agency

and

U.S. Department of Energy

Through an agreement with

National Aeronautics and Space Administration

by

Jel Propulsion Laboralory

Calitorna Institule of Technology

Pasadena. Califorma 
Prepared by the Jue fropulsion Laboratory, California Institute of Technology, for the U.S. Departanent of Eneugy through an agresment with the National Aeronautics and Space Administration.

This report was prepared as an account of work sponsored by the United States Governmeni. Neither the United States nor the United States Department of Fnergy, nor any of their employes, nor any of their contractors, subcontractors, or their employees, makes any wirranty, express or implied, or assumes any legal liability ur responsibility for the aceuracy, completeness or usefulness of any information, apparatus, product or process diselosed, or represents that its use would not infringe privately owned rights. 
A study of potential future hydrogen markets in the United States was performed for the International Energy Agency's (IEA) Hydrogen Program Anmex III, "Assesament of Potential Euture Narkets for the Production of Hydrogen from Water." The study was sponsored by the U.S. Department of Energy, Energy Storage Systems Division, as the U.S. contribution th Annex III, and conducted by the Jet Propulsion lishoratory ander its Hydrogen Energy Storage Teclmology Project.

The study projects future hydrogen markets for various use sectors, estimates the probable range of hydrogen production costs from various alternatives, discusses stimuli and barriers to the development of hydrogen markets, presents an overview of the status of technologies for the production and utilization of hydrogen, and, Finally, discusses societal aspects of hydrogen production and utilization. 


\section{ACKNOWLEDGMENTS}

The author vishes to recognize the contributions of the following individuals who participated in this study. Their inputs form the basis for this report:

(1) James H. Kelley, Manager of the Project and U.S. reprecentative to the IEA Hydrogen Program Annex III, for details on barriers to development of hydrogen markets.

(2) Kenneth $K$. Tang for his contribution concerning existing market developrest and stimulating factors for the development of hydrogen markets in the United states.

(3) Christopher Fngland for reviewing the cost of hydrogen production.

(4) Shaik A. Quader for his early input in the hydrogen market demand projections and hydrogen production technologies. 
1. INTRODUCTION

2. RESULTS

2.1 MARKET DEVELOPMENT

2.1.1 FXISTING MARKETS -

2.1.2 NEW MARKETS

2.2 STIMULATING FACTORS FOR DEVELOPMENT OF HYDROGEN

MARKETS IN THE UNITED STATES

2.2.1 FAC'TORS IMPACTING HYUROGEN DEMAND IN EXISTING MARKETS - 14

2.2.2 STIMULATING FAGTORS FOR DEVELOPING NEN MARKETS

2.3 BARRIERS TO DEVELOPMENT OF HYDROGEN MARKETS -

2.4 TECHNOLOGY

2.4.1 HYDROGEN PRODUCTION TECHNOLOGY

2.4.2 STORAGE, TRANSMISSION, AND DISTRIBUTION OF HYDROGEN - - 30

2.5 RCONOMICS OE HYDROGEN PRODUCTION

2.5.1 HYDROGEN FROM GOAL 35

2.5.2 HYDROGEN FRON THERMOCHEMICAL SPLITTING OF WATER -

2.5.3 HYDROGEN FROM WATER ELECTROLYSIS

2.6 SOCIETAL ASPECTS - 42

2.6.1 ENVIRONMENTAL IMPAC'S OF HYDROGEN PRODUCTION $-\cdots$

2.6.2 ENVIRONMENTAL IMPACTS OF UTILIZING HYDROGEN AS A FUEL $\rightarrow-\infty 9$

2.6.3 SAFETY ASPECTS OF HYDROGEN 50

2.6.4 LEGAL AND INSTITUTIONAL \& SSUES OF HYDROGEN ENERGY -...- 51

3. CONCLUSIONS

GLOSSARY - 55

REFERENGES 


\section{LIST OF FIGURES}

1. Hydrogen Demand in the U.S. Ammonia, Methanol, and Refining Industries (from Reference 1) -

2. Total Projected Hydrogen Supply in the U.S. Refining Industry (from Reference 1)

3. Total Projected Hydrogen Demand in the U.S. Refining Industry (from Reference 1) 7

4. Total Projected Hydrogen Demand for Hydrotreating in the U.S. Refining Industry (from Reference 1) -........ 9

5. Hydrogen Production through Hybrid Thermochemical Sulfur Cycle Frocess (from Reference 5) 23

6. Generalized Process Flow Scheme for Converting Coal into llydrogen (from Reference 7) 26

7. Koppers-Totzek Gasification System -- Simplified Flow Diagram - 28

8. Sensitivity of Hydrogen Production Costs to Coal Cost

9. Sensitivity of Hydrogen Production Costs to Nuclear Fuel Cost for Hybrid Thermochemical Sulfur Cycle plant using a Dedicated HTGR - 39

10. Sensitivity of Hydrogen Production Costs to Electricity Cost for a Small-scale SPE Electrolyzer

11. Sensitivity of Hydrogen Production Costs to Nuclear Fuel Cost for a Large Central SPE Electrolyzer using a Dedicated HIGR 


\section{LIST OF TABLES}

1. Total Projected Hydrogen Demand for Various Sactors in the United States $10^{18} \mathrm{~J}\left(10^{15} \mathrm{Btu}\right) /$ year

2. Magnitude of Barriers to Utilization -- the Manufacture of Hydrogen: Tentative

Characterizations (From Reference 4)

3. Estimated Magnitude of Barriers to Utilization -Transmission and storage: Tentative

Characterizations (from Reference 4)

4. Estimated Magnitude of Barriers to

Utilization -- End Users: Tentative Characterizations

(Erom Reference 4 )

5. Cost of Hydrogen from Coal Gasification

(1978 Dollars)

6. Hybrid Sulfur Cycle Plant Capital Cost Summary -- 1978

Basis (Erom Reference 5) 40

7. Cost of Hydrogen from a Hybrid Thermochemical

Sulfur Cycle Plant (1978 Dollars)

8. Cost of Hydrogen by the Electrolysis of Water

(1978 Dollars) - 43

9. Cost of Hydrogen by the Electrolysis of Water using a Dedicated HTGR (1978 Dollars) 
The objective of this study was to assess the potential future markets for hydrogen in the United States with specific regard to the development of new markets in the energy sector. Technical feasibilities and problems as well as economic aspects of hydrogen production and application are discussed. Stimulating factors and barriers to the development of hydrogen markets are presented, and, finally, the societal aspects of hydrogen production and ytilization are summarized.

This study was projected for a period of fifty (50) years, i.e., for the period between 1975 and 2025. The results presented in this report are based on findings, information, and documents that were available prior to December 1979. In the preparation of this report, the latest version of the common framework (issued by the Operating Agent for Task III of the International Energy Agency (IEA) Hydrogen Program) was taken into account, and the market for hydrogen was outlined in the manner requested by the Operating Agent for Task III of the IEA Hydrogen Program. To comply with the common framework, cost figures are expressed in $1978 \mathrm{U} . \mathrm{S}$. dollars. Also, the economic evaluations were based on constant $1978 \mathrm{U.S}$. dollars; i.e., the rate of inflation was not taken into consideration.

2.

RESULTS

2.1 MARKET DEVELOPMENT

2.1.1 EXISTING MARKETS

The industrial hydrogen demand shown in Table 1 represents the hydrogen requirements for existing markets such as those of petroleum refining and ammonia and methanol manufacturing, as well as the requirements of a variety of small users such as those in the edible oil industry, chemical and plastic industries, and direct iron reduction and welding industries.

\section{PETROLEUM REFINING}

The overall energy situation is undergoing drastic changes in the United States. This changing energy situation will create corresponding alterations in the refining industry, and these will have significant impacts on the hydrogen marketplace:

(1) Gasoline demand is projected to level off about 1980 and then to decline as a percentage of energy production. This will cause a general decrease in the amount of hydrogen produced by catalytic reformers. 
Table 1. Total projected Hydrogen Demand for Various Sectors in the United states $-10^{18} \mathrm{~J}\left(10^{15} \mathrm{Btu}\right) /$ year

\begin{tabular}{|c|c|c|c|c|}
\hline Sector & 1978 & 1985 & 2005 & 2025 \\
\hline $\begin{array}{r}\text { Industrlal } \\
\text { Refinery }\end{array}$ & $0.37(0.35)$ & $0.47(0.43)$ & $0.6(0.5)$ & $0.7(0.7)$ \\
\hline Chemfeal & $0.68(0.65)$ & $0.73(0.67)$ & $1.8(1.7)-2.0(1.8)^{1}$ & $3.0(2.8)-4.0(3.8)^{2}$ \\
\hline Synfuel & $-m$ & --- & $4.0(3.7)-4.4(4.0)^{3}$ & $13,4(12,2)-11,6(16.9)^{4}$ \\
\hline Transporta- & $-m$ & $m-m$ & $0.9(0.8)-1.0(0.9)^{5}$ & $2.4(2.2)-3.9(3.5)^{6}$ \\
\hline $\begin{array}{l}\text { Natural gas } \\
\text { supplement }\end{array}$ & -- & -- & $0-0.5(0.5)^{7}$ & $0-0.3(0.3)^{7}$ \\
\hline Fuel cells & $-\infty$ & $-\infty$ & $0-0.2(0.2)^{8}$ & $0.5(0.5)-0.7(0.6)^{8}$ \\
\hline Total & $1.05(1.00)$ & $1.2(1.1)$ & $7.3(6.7)-8.7(7.9)$ & $20.0(1.8 .4)-28.2(25.8)$ \\
\hline
\end{tabular}

Supersertpts indiente the following assumptions:

$1-3-4 \%$ anmual growth in hydrogen demand for chemienl industries during perfod 2000-2010 (based on projected annual growth for chemteal dndustrtes during this pertod)

$2-2-3 \%$ annual growth in hydrogen demand for chemfol Industries during 2010-2025 (based on projected growth for chemical Industries during this period)

3 - 10-12\% anmul growth in synfuel industry during period 19922010 (based on projectod growth synfuel industry in the U.S. for this period)

4 - 5-6\% annual growth in synfuel industry during pertod 2010-2025 (based on projected growth for synfuel industry in the U.S. For this period)

5- 8-10\% anmual growth in hydrogen demand for aviation during $2000-2010$

$6-4-6 \%$ annual growth in hydrogen demand for aviation during period 2010-2025

7 - The natural gas used will be mixed with hydrogen ( $10 \%$ for the year 2225 and $15 \%$ for the year 2025).

$8-7-10 \%$ growth during the period 2000-2010 and about $5 \%$ during the period 2010-2025. 
Table 1. Total Projected Ilydrogen Demand for Vaxious Sectors in the United states - $10^{18} \mathrm{~J}\left(10^{15} \mathrm{Btu}\right) /$ year

(Continuntion 1)

\begin{tabular}{|c|c|c|c|c|}
\hline Sector & 1978 & 1985 & 2005 & 2025 \\
\hline Non-energy & $0.68(0.65)$ & $0.73(0.67)$ & $1.8(1.7)-2.0(1.8)$ & $3.0(2.8)-4.0(3.8)$ \\
\hline $\begin{array}{l}\text { Enorgy } \\
\text { Indtreet }\end{array}$ & $\therefore .37(0.35)$ & $0.47(0.43)$ & $4.6(4.2)-5.0(4.5)$ & $14.1(12.9)-19.3(17.6)$ \\
\hline $\begin{array}{l}\text { Energy } \\
\text { direct }\end{array}$ & $m-m$ & $-m$ & $0.9(0.8)-1.7(1.6)$ & $2.9(2.7)-4.9(4.4)$ \\
\hline lotal & $1.05(1.00$ & $1.2(1.1)$ & $7.3(6.7)-8.7(7.9)$ & $20.0(18.4)-28.2(25.8)$ \\
\hline
\end{tabular}

Non-energy = ammonfa and methanol manufacturing as well as small users such as the edible ofl Industry, chemical and plastie Industries, and dreet fron reduction and welding Industries

Energy direct = Transportals + Natural gas supplement + fuel cells

Energy Indirect $=$ Synfuel + Refinery 
(2) Distillates demand will increase substantially. particularly in the residual fuels area, leading to an increased demand for hydrotreating and a greater hydrogen requirement.

(3) The amount of sour crude supplied to refineries has shown an increasing trend, and this requires increased hydrotreating to remove the sulfur from the products.

(4) Environmental regulations pertaining to sulfur oxide emissions will continue to tighten; as sulfur percentages in the various fuele decrease, the demand for hydrogen in hydrotreating will inctease.

These trends in the refining industry indicate an increasing demand for hydrogen and the overall importance of the use of hydrogen in refinery operations. Figure 1 shows the hydrogen demand of refineries compared to those for ammonia and methanol production (the largest single users of hydrogen). The hydro-treating and hydrocracking demand of refineries for hydrogen is about one-lialf of the demand for ammonia manufacturing and is nearly twice that for methanol manufacturing.

The overall hydrogen supply at the refinery sites (from catalytic reformers and hydrogen generators) is almost twice the refinery demand. There is a surplus of about 34 million standard cubic meters ( $1.2 \times 10^{9}$ cubic feet) per day of hydrogen for the industry as a whole (Reference 1). However, this overcapacity in hydrogen production does not exist in every refinery; some are in extremely short supply and must generate their own hydrogen.

Figures 2 and 3 present projected hydrogen supply and demand. Supply comes mainly from gasoline reforming byproducts and is supplemented by hydrogen from plant hydrogen. The hydrocracking and hydro-treating demand components show substantial increases at the expense of the surplus byproduct, which is normally used for fuel. It is important to analyze the hydrotreating demand for hydrogen because it shows the greatest single increase in the overall demand. Figure 4 shows the dramatic increases in hydrogen demand for gas oil, distillate, and atmospheric residual oil. Hydrogen demand for gas oil will double within a five-year time frame.

AMMONIA

If fully utilized, the production capacity in the United states for producing anhydrous ammonia is estimated to be more than 85 million cubic meters $\left(3 \times 10^{9}\right.$ cubic feet) per day of hydrogen. This is by far the largest marliet for hydrogen in the United States. The United states capacity estimated above is based almost entirely on plants with integrated methane reforming and ammonia synthesis. 


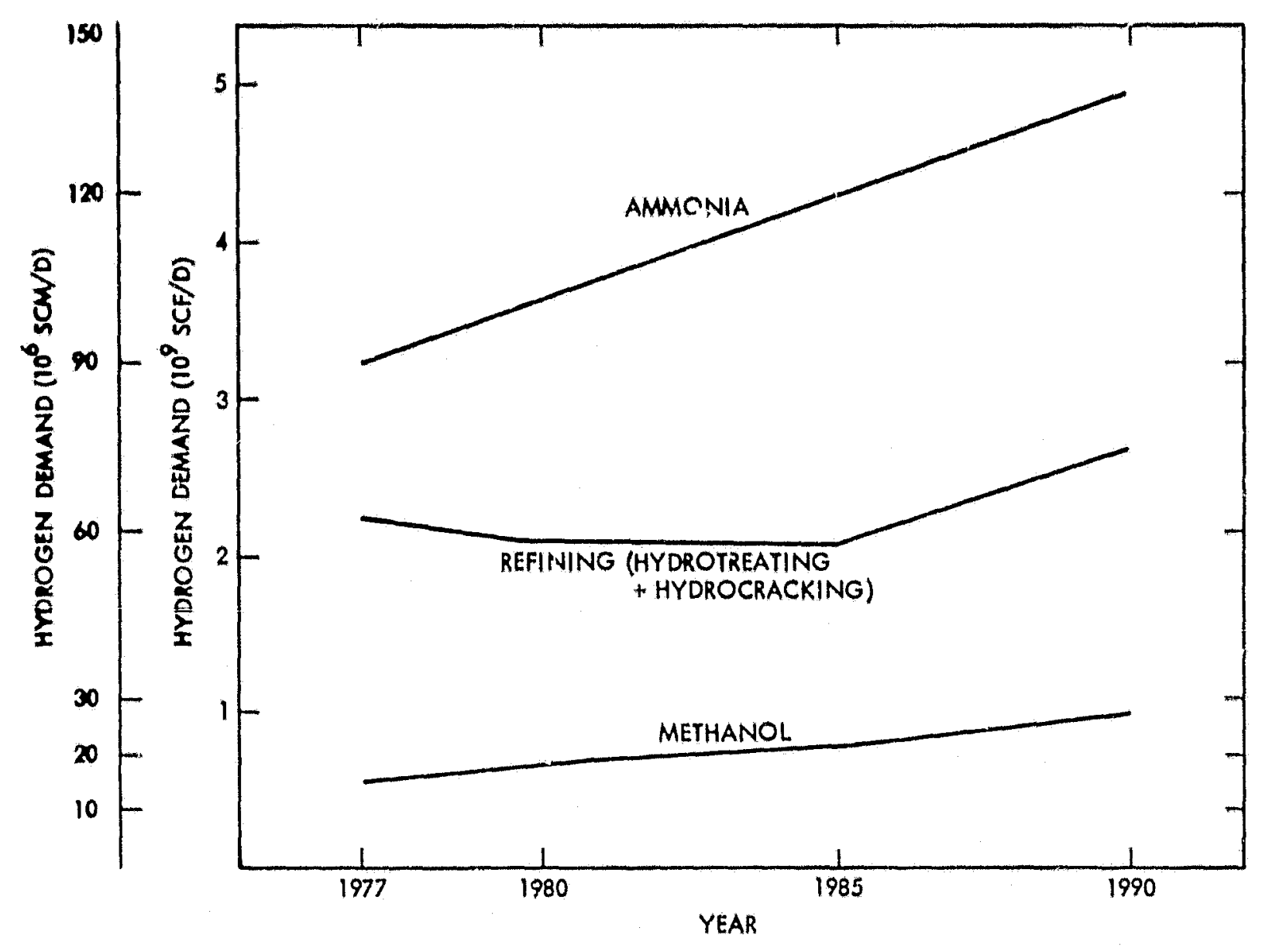

Figure 1. Hydrogen Demand in U.S. Ammonia, Methanol, and Refining Industries (From Reference 1) 


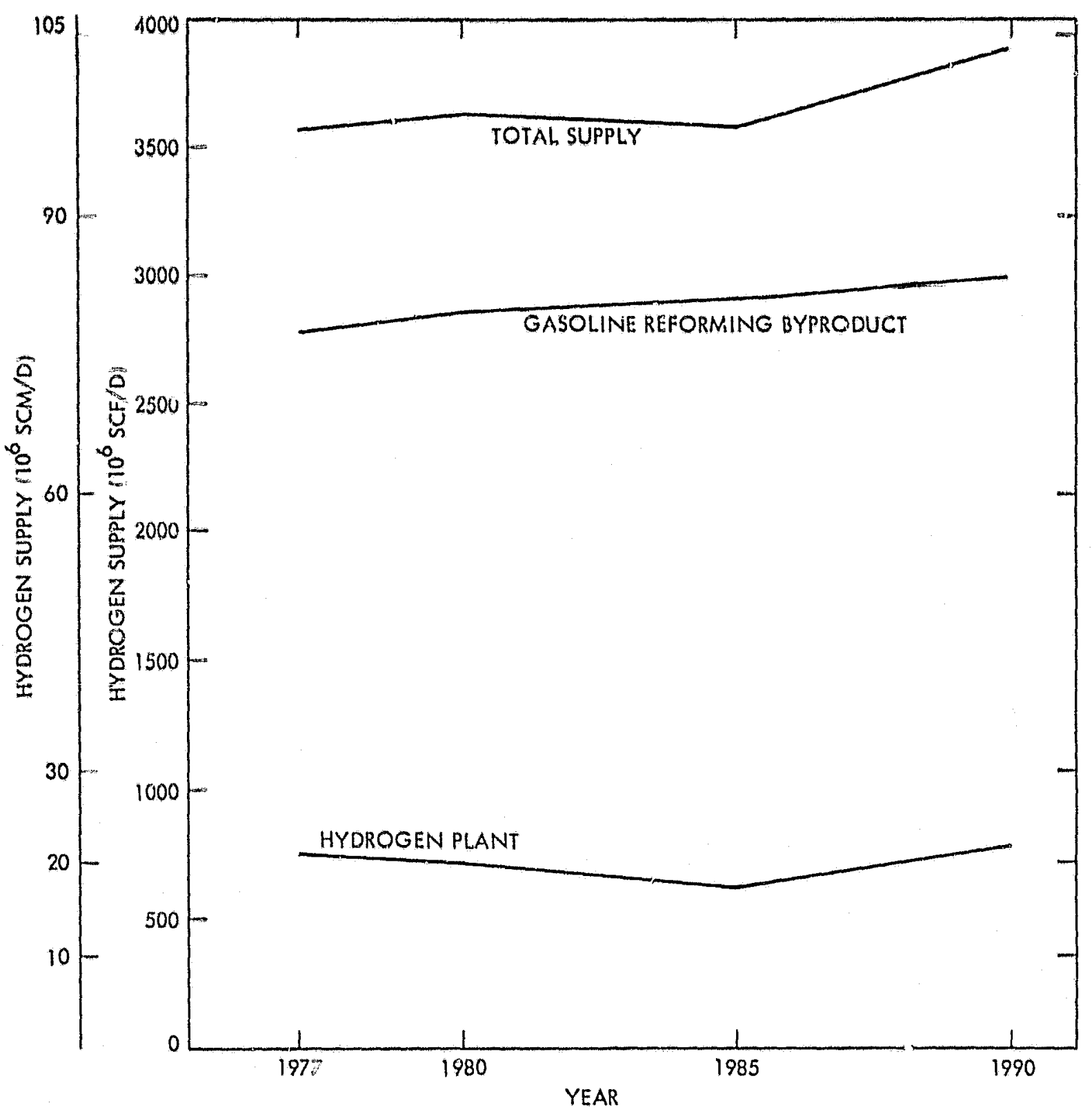

Figure 2. Total Projected Hydrogen Supply in the U.S. Refining Industry (from Reference 1) 


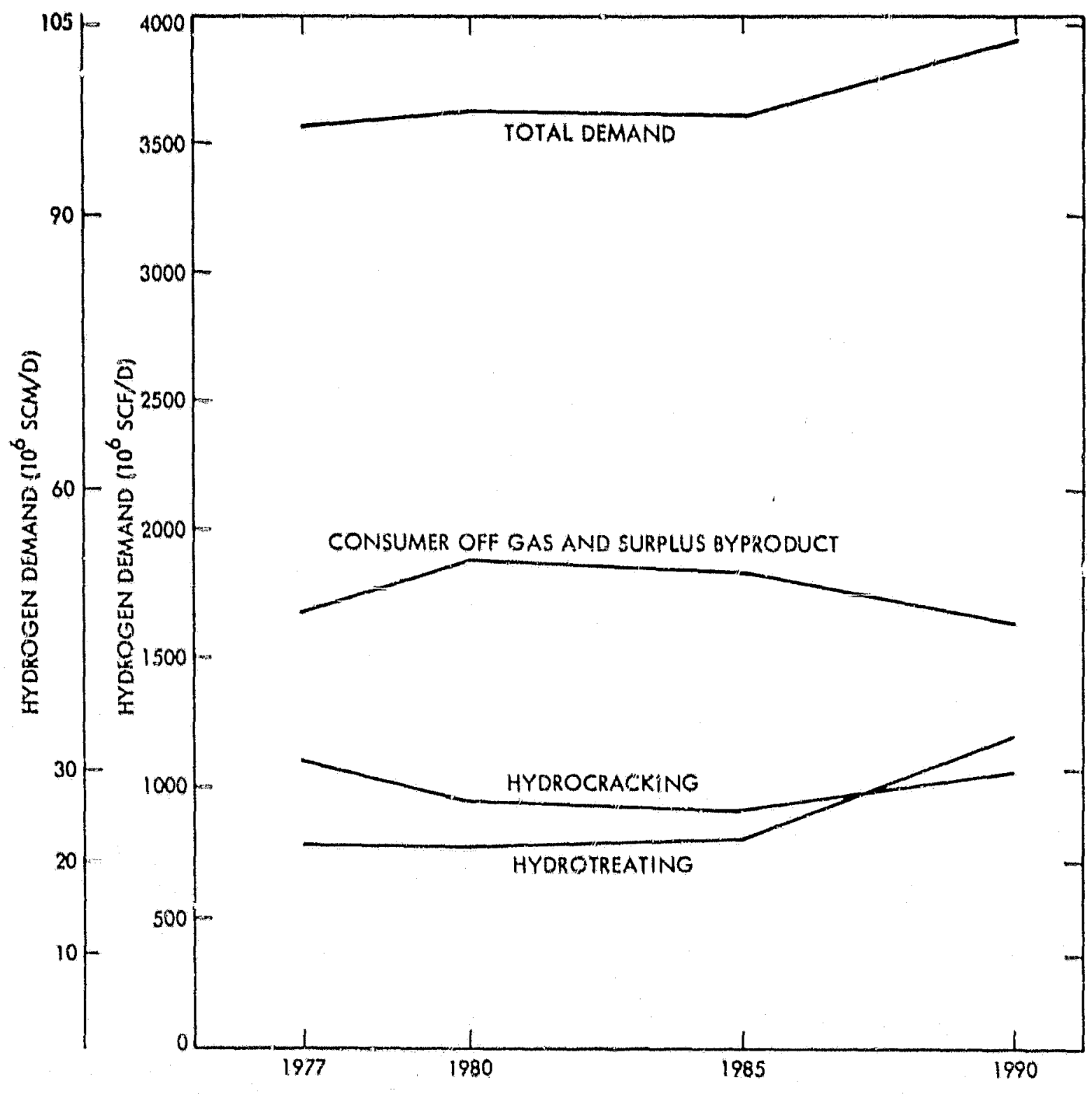

Figure 3. Total projected Hydrogen Demand in the U.S. Refining Industry (from Reference 1) 
As of 1977 , a substantial excess in ammonia production capacity existed in the United States. Ammonia prices had roughly quadrupled between the early- and mid-1970s, and capacity was increased about $25 \%$ during the 1974-1978 period in response to higher prices and profits. About 6000 tons per day of the total expansion was brought on-line during 1978 and is therefore included in this study. The demand for ammonia increased about $7 \%$ during the 1974-1978 period (Reference 2). By 1977, ammonia prices were back to the 1974 levels. Because natural gas prises increased substantially between 1974 and 1977,1977 antmonia prices were in some cases insufficient to cover variable costs, and a substantial number of plants were shut down.

The possibility of major ammonia imports to the United States arose in 1977 . The fundamental valuation difference between shut-in foreign natural gas and domestic natural gas prices has encouraged the exportation of energy values in cummodity forms such as ammonia. Various sources have projected that as much as $25 \%$ of the U.S. consumption of ammonia equivalents will be imported by the early 1980 s.

The outlook for an increase in capacity, and therefore in hydrogen capacity requirements for U.S. ammonia production, depends upon when existing piant shutdown capacity is restarted as well as on the level of future imports.

With 1978 ammonia requirements at 16.5 million tons and with an effective capacity of $19.5 \mathrm{million}$ tons, no incremental capacity (above the mid-1970's commitments) will be required through 1982 (Reference 2). Even with the assumption of no imports (which will not be true) the three million tons of excess capacity will accommodate the expected United States annual ammonia market growth of $3.7 \%$.

The increases in domestic capacity for the production of ammonia during the 1983-1987 period appear to depend upon future amonia import levels. A range of 2-4 million tons of imports has been projected by 1982. Even if the upper end of that import range is not reached until 1987, no domestic capacity additions will be required during the 1983-87 period. Recently some domestic anmonia producers have attempted to limit the level of imported ammonia by requesting an import duty "that would enable domestic producers to operate at reasonable levels of profit and at appropriate rates of capacity ..." (Reference 2.) The outcome of the import duty request will eventually reach congress and will be resolved by the political process. At this time it does not appear likely that ammonia import duties will be imposed at a level sufficiently high to permit new U.S. capacity expansion based solely on conventional natural gas technology during the 1983-1987 period (Reference 2). 


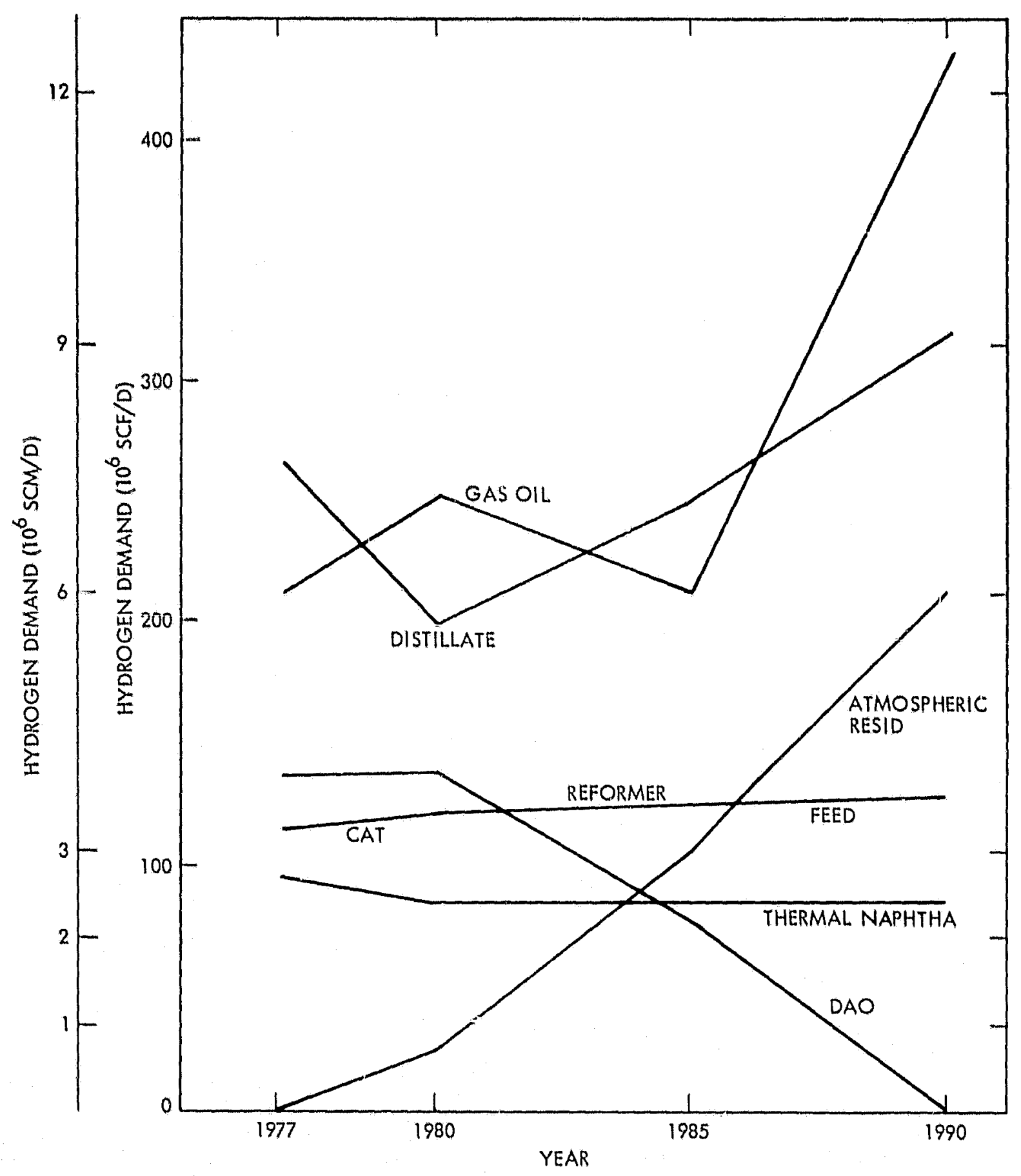

Figure 4. Total Projected Hydrogen Demand for Hydrotreating in the U.S. Refining Industry (from Reference 1) 
METHANOL

Methanol is an important hydrogen and carbon-monoxideconsuming product in the United States; next to ammonia, it provides the largest chemical-industry market for either hydrogan or syngas.

Throughout the 1960s and early 1970s, the U.S. demand for methanol increased at a substantially faster rate than the overall U.S. economy. This was primarily because of the above-average growth of housing and construction markets which required increasing amounts of formaldehyde made from methanol. Also, key methanol derivatives were introduced, and these became part of very high-growth markets, During the 1960s, for example, the use of dimethyl terephthalate expanded in parallel with the use of polyester fiber. A technology for the conversion of methanol to acetic acid that was introduced in 1970 opened up major indirect growth areas for methanol in the production of vinyl acetate and terephthalic acid. Methanol demand peaked in 1973 at over $1 \times 10^{9}$ gallons ( 3.78 million cubic meters), a level somewhat above the combined 1977 U.S. domestic and net export levels (Reference 2).

The importation of methanol is projected to increase moderately, but no flood of imported methanol on United States markets is expected.

\subsubsection{NEW MARKETS}

\section{SYNFUEL SECTOR}

The manufacture of usable gaseous and liquid fuels from sources such as coal, shale, and tar sands all require hydrogen. This role of hydrogen in the manufacture of synthetic fuels constitutes a major application for hydrogen that will rapidly grow in importance, as primary energy sources such as coal and shale are implemented. In the transportation sector, for example, synthetic gasoline derived from coal liquefaction or oil shale is a strong contender for replacing petroleum-based gasoline, due particularly to its compatibility with the existing distribution system. Use of coal-derived substitute natural gas (SNG) is similarly a primary candidate for replacing natural gas since it can be used in existing distribution systems and end use devices without any modification to equipment.

The synfuel hydrogen demand reported in Table 1 represents hydrogen requirements for synthesizing high-Btu gas, low-Btu gas, and synthetic liquid fuels from coal and shale. The demand for hydrogen in this sector is expected to be about $4 \times 10^{18}$ Joules $\left(3.7 \times 10^{15}\right.$ $B(u)$ in the year 2000 , and at $3 \frac{1}{2}$ times this quantity, it will represent about $65 \%$ of the total hydrogen demand in the year 2025 .

This estimated demand is based on production of approximately 1.5 million barrels per day crude oil, equivalent of synthetic fuel from coal and shale by 1992 , assuming reasonable growth for the industry after that (10-12\% annual growth during 1992-2010 and another $5-6 \%$ yearly growth to the year 2025 ). 
Assuming that all of the hydrogen projected for manufacturing synfuel goes to the production of liquid fuel from coal, the projected hydrogen in the synfuel sector would produce $5.6-6.1 \mathrm{million}$ bbl/day of synthecic crude by the year 2005 and 18.5-25.6 million bb1/day of synthetic crude by the year 2025. In our opinion, the quantity projected for the year 2005 is realistic and can be achieved, but we have some reservatione regarding projection for the year 2025 . The main constraint is the availability of 185-256 sites in the country for constructing large synfuel plants, considering societal, and, in particular, environmental impacts associated with each plant.

\section{TRANSPORTATION SECTOR}

Hydrogen can serve as a low-pollution fuel for the transportation sec-or. At present, the transportation sector is supplied almost exclusively by petroleum-derived fuels. However, it appears likely that well-established petroleum fuel-based systems will continue to dominate as long as petroleum is available in sufficient supply. After this period the strong candidates for replacing petroleum-derived fuels are coal or oil shale-derived fuels encompassing synthetic gasoline, methanol, and others.

The primary advantage of the coal and oil shale-derived fuels is that they can be implenented with essentially no changes in present vehicles. Further, the existing distribution networks can be employed. The economic incentive of using the large capital investment in present systems favors fuels which can be used as direct substitutes for present petroleum fuels. Thus, it is unlikely to perceive a major shift to alternatives such as electric propulsion or hydrogen for the transportation sector in the next 45 years. Shifts to alternatives such as electric propulsion or hydrogen will require substantial capital investments which would limit their use in the context of availability of coal or oil shale-derived fuels that are compatible with existing vehicles and fuel distribution systems.

2.1.2.1 Ground Vehicles. The major technical difficulty with using hydrogen as a fuel in ground vehicles is storage. In gaseous form, compressed gas tankage volume and weight require compromises which would limit the travel range. Cryogenic liquid storage entails additional cost and handing complexity. Hydride storage systems solve some of these problems but have many others peculiar to hydride storage such as sensitivity to contaminants, deformation ( 1 ife), and thermal control.

Also, a large hydrogen fuel distribution network must be provided if hydrogen is to be used on a large scale. Since this requires large capital expenditures, it is likely that hydrogen usage be accomplished in a gradual manner. For reasons of improved air pollution or other special purposes such as fork lifts in building construction, some small usage of hydrogen is likely. However, for purposes of formulating a solid reference level of usage, no demand for hydrogen in the ground vehicles is included in these projections. 
2.1.2.2 Water Vehicles, Conversion of ships to hydrogen would require large scale reffueling provisions to be provided at harbors, for transoceanic ships, and this implies establishment of intarnational re-fueling stations in addition to internal conversion of ships. The vast bulk of water shipping occurs away from heavily populated areas where nix pollution is not a critical or immediate health hazard problem. Thus, there is no environmental necessity that would cause conversion of ships to hydrogen. From these overall considerations, it follows that in the next 45 years in the United States, it would be unlikely for ships to convert to hydrogen.

2,1.2.3. Aircraft and Space Vehicles. Cryogenic liquid hydrogen provides potential performance advantages for both subsonic and supersonic aircraft. Basically, hydrogen has a much higher energy content per unit weight as compared to jet fuel. This results in a lighter fuel load and an overall weight savings which provides performance advantages in airborne vehicles. For this reason, hydrogen has been used in space-launched vehicles for the past two decades.

These factors indicate that conversion to hydrogen fucl will be economically viable for aircraft sooner than for ground or water vehicles. Further, aircraft fueling and maintenance are performed by highly trained crews and this will fwcilitate introduction of a cryogenic hydrogen fuels technology.

However, development time and cost of the new aircraft system and the establishment of an airport hydrogen wefueling network on a worldwide basis are factors which reduce the possibility of any wide-scale conversion. Factors such as performance advantages for military missions or even requirements for reduced air pollution near airports could stimulate hydrogen airplane development.

From these overall considerations and taking into account lead time required for design, development, and production of the new nircraft, it is conceivable that $10 \%$ of the aviation fuel will be supplied by hydrogen in the year 2000. The projected hydrogen demand reported in Table 1 for this sector assumes a reasonable market penetration for this type of aircraft after the year 2000 (8-10\% annul growth rate during the period $2000-2010$ and $4-6 \%$ growth rate per year after that).

\section{NATYUKAL GAS SUPPLEMENT SEGTOR}

The main synthetic gaseous fuel alternative to hydrogen appears to be substitute natural gas (SNG). On a per-unit-of-energy basis, natural gas (and/or SNG) is less expensive to transmit via pipelines. However, SNG is more difficult to manufacture from coal and will require more capital.

SNG has the advantage of being a direct replacement for natural gas. Existing distribution netrorks and utilization equipment (Eurnaces, water heaters, etc.) can be used without modification. Use 
of hydrogen will, in general, require some modification of equipment. It has been reported that a mixture of $10 \%$ hydrogen and $90 \%$ me thane has been used in existing appliances without any difficulty.

In corisideration of the above factors, the projected hydrogen demand for this sector in the United $S$ tates is shown in Table 1. This projection is based on the assumption that all natural gas in the United States will be supplemented with hydrogen to the average extent of $10 \%$ by volume for the year 2005 and to $15 \%$ by 2025 .

\section{FUEL CELLS SECTOR}

In the future, fuel cells, most likely, will be used as the spinning reserve capacity for a utility system, since the fuel cell has a relatively flat heat rate characteristic. This then allows the cycling steam plants to operate at their most efficient point, and results in reduced system operating cost (Reference 3 ). Another attractive application of fuel cell is for meeting increased loads in urban areas having restrictive pollution standards and 1 imited potential for new transmi:sion rights-of-way. Finally, the fuel cell may be used for dual energy production (cogeneration). The demand estimated for this sector is based on production of 1500 MWe with fuel cells by the year 2000 ; it also assumes $7-10 \%$ annual growth for this sector during the period 2000-2010 and $5 \%$ per year after that. It should be noted that hydrogen demand for this sector will be much higher and its use more efficient if fuel cells are utilized in distributed systems for dual energy production (cogeneration).

\subsection{STIMULATING FACTORS FOR DEVELOPMENT OF HYDROGEN MARKETS IN THE UNITED STATES}

At present, most of the hydrogen that is used in she United States is produced in connection with chemical manufacturing and oil refining processes, and it is consumed either "on-site" or in nearby plants as either a raw material or a fuel. This "captive" hydrogen is produced and used by such industrial users as ammonia and me thanol inanufacturers, oil refineries, acetylene, ethylene and butadiene plants, and by other chemical processing plants. The remainder (less than $1 \%$ of the total), is produced for sale by industrial gas companies, and is known as merchant hydrogen.

In practice, all hydrogen currently used in the United States is produced from either natural gas or petroleum fractions, and requires a significant amount of energy. Therefore, the future growth (or lack of growth) of hydrogen demand will be linked directly to future energy developments in the United States. Similarly, factors which will stimulate the development of new hydrogen markets will be affected directly by trends in the overall U.S. energy picture.

For example, if the United States is successful in greatly accelerating the development of a synthetic fuels industry based on the gasification and liquefaction of coal, then the synfuel market for 
hydrogen will be very large. On the other hand, the lack of significant growth in the synfuels area would reduce the projected demand for hydrogen by a very substantial factor.

The following discussion is divided into two parts: first, factors that affect hydrogen demand in the major existing U.S. markets (refining, chemical), and second, factors that stimulate the development of new U.S. markets.

\subsubsection{FACTORS IMPACTING HYDROGEN DEMAND IN EXISTING MARKETS}

Hydrogen demand in the U.S, refining industry is expected to increase substantially because of accelerated hydrotreating requirements. The factors causing this increased requirement include: the rapidly rising demand for gas oil, distillate, atmospheric residual oil, the increased use of sour cruce, and tighter regulations on sulfur oxide emissions (Reference 1).

Hydrogen demand in the U.S. ammonia industry, is not expected to rise significantly in the near future. Nearly all of the estimated U.S. capacity is based on plants that use integrated methane reforming and ammonia synthesis. Factors affecting demand in this market include: substantial excess capacity in the U.S., rising costs and falling prices, and the prospect of major imports of ammonia to the United states from abroad.

Hydrogen (and carbon monoxide) demand for methanol production in the United States could become very significant in the future, especially if methanol becomes an important element of the U.S. fuel supply. In the chemical industry, the demand for methanol has been rising faster than the overall U.S. economic growth. Factors affecting this demand include a high demand for formaldehyde by the housing and construction industries, and the introduction of key methanol derivatives into several chemical markets.

\subsubsection{STIMULATING FACTORS FOR DEVELOPING NEW MARKETS}

In addition to the growth of existing markets for hydrogen in the industrial sector, as discussed above, projected uses have been made by various groups for possible markets in the Future. The purpose of this discussion is not to debate the merits of specific projections, but to enumerate the factors that could act as stimuli to the future development of hydrogen markets in the United States.

\section{ENVIRONMENTAL FACTORS}

Many geographic areas in the U.S. have serious air pollution problems. In these areas, the increasing concern for human health may eventually lead to the mandating of more costly but cleanerburning fuels for utilities, industries, and transportation systems. Because hydrogen is a clean-burning fuel that can be stored, it would 
be a strong candidate for this service. The gbove sectors represent a potential market where the social costs could dominate economic considerations alorie.

A more global factor than the one above is the atmospheric $\mathrm{CO}_{2}$ problem. If the adverse effects of the continuing rise of $\mathrm{CO}_{2}$ concentration are confirmed to be a definite problem linked to the combustion of fossil fuels, then the United States, being the largest consumer of fossil furels, would have to take steps to reduce its $\mathrm{CO}_{2}$ production from fossil fuel combustion. In that event, hydrogen and electricity could become complementary energy carriers for aystems based on either solat, geothermal, or nuclear energy.

\section{POLITICAL FACTORS}

To the extent that the United States acts to limit the importation of foreign petroleum, the demand for domestic sources of energy and feedstocks will be accelerated. This acceleration will be a significant factor in stimulating the development of hydrogen markets, many of which will be new for the United States. These markets include its use in the production of various synthetic fuels from coal, for the supplementation of natural gas, for use in various refining and chemical processes, and as a transportation fuel.

Past energy forecasts and projections in the United States usually have relied heavily on nuclear fission as a principal energy source of the future. The outlook for the growth of nuclear power in the United states is becoming less optimistic, however. If the present trend continues, there will be a further incentive for the United States to increase its use of domestic coal, oil, and gas (as well as hydro, solar, and geothermal, the "renewable" energy sources) in order to replace nuclear energy. This would be another factor for stimulating the hydrogen market development.

\section{TECHNOLOGICAL FACTORS}

The successful development and commercialization of advanted systems for producing hydrogen at competitive costs would stimulate new market development, as would the demonstration of advanced power systems such as OTEC, where hydrogen could be the ideal energy carrier.

Advances in fuel ceil technology could make tiydrogen more atrractive for decentralized power systems. The extent of this market could well be much larger than shown in the projections.

Improved storage technolugy could be a key to the transportation-Euel market as well as for utility energy storage.

If methanol from coal becomes a major factor in the U.S. fuel supply, a large market for hydrogen (and carbon monoxide) would be developed. 
Three major areas must be considered in the implementation of hydrogen as an energy carrier. These are production, transportation and storage, and utilization. Barriers to development in each of these areas are summarized in the following paragraphs.

A general barrier to the production of hydrogen as an energy carrier is the fact that markets for hydrogen do not presently exist. Investors do not wish to build large plants with the risk that anticipated markets do not develop or that they would not be stable. Also, alternative production approaches to the steam reforming of natural gas, including, solar, nuclear and coal, are all more expensive at this time than the production of hydrogen from natural gas. Natural gas is a more convenient energy form, so hydrogen will not be produced as a fuel from natural gas except for special uses such as rockets. Production of hydrogen from coal is at present the state-of-the-art, although capital cost is fairly high, and environmental problems exist in both the mining and transport of coal and in the gasification system itself. There are problems with the siting of gasification plants and with water usage as well as with pollution. Because product hydrogen is a gas, rather than a liquid, it must be transported as a gas or made into a cryogenic liquid for transporting. This would be desirable in large quantities only if the final product were to be a liquid.

Hydrogen from nuclear energy will require high-temperature nuclear reactors. These have not been developed to the point of commercial implementosion in the United States. In addition to cost, the strongest barrier is that nuclear energy has not yet found widespread politichl support and this has resulted in siting and approval problems. There are also claims of environmental and safety problems. This may push the implementation of large nuclear plants well into the future. Conversion of nuclear heat to hydrogen will require either thermochemical systems, which have not yet been proven, or conversion to electricity and then to the electrolytic production of hydrogen. The advanced electrolyzers which would be needed are only in the developmental stage. The energy conversion process to electricity and then to hydrogen through electrolyzers is capital-intensive and not very efficient.

In areas of transportation and storage, hydrogen suffers from a low volumetric energy density, having approximately one-third the energy of natural gas per uitit of volume. In gaseous storage or transport systems, this is not offset by the fact that it has three times the energy per pound of natural gas. Another barrier in the transport and storage area is that no large systems currently exist for transporting and storing hydrogen. The largest systems are for liquid hydrogen, and these are in the space program. At present larger quantities of hydrogen are now transported as a liquid in trucks, barges, or railcars. Storage or transport as a gas in tanks or as a hydride, requires relatively heavy systems, weighing from 50 to 200 times the amount of hydrogen contained. This poses a distinct disadvantage in transportation with regard to both capital costs and 
energy usage. It ffects adversely the tationary systems only from a cost standpoint. Another barrier is embrittlement and stress corrosion of containment materials. At high pressures, hydrogen tends to attack containment material such as steels, leading to failurs of systems which would have been designed for other high pressure gases, such as natural gas. A further barrier is safety. Hydrogen has wide flammability limits and leakage in enclosed areas would create a severe safety hazard. Also leaking hydrogen from high pressure systems tends to autoignite, forming a flame at the source of the leak. To aggravate this situation, the flame is clear and would not be seen. Further, hydrogen is odorless. Odurants which are added to natural gas are sulfur based compounds. These sulfur compounds aggravate the compatibility problems usually associated with hydrogen gas.

Barriers to the uses of hydrogen include the unavailability of a supply and distribution system and the present high cost of hydrogen. Fuel cells are developed as an early use of hydrogen. Low and high temperature fuel cells with an efficiency on the scale of $35-40 \%$ and $40-50 \%$, respectively, have not been developed to the point of commercialization. Hydrogen could be supplied to these fuel cells by a pipe from a central hydrogen production plant. For vehicular use, there are difficulties associated with onboard storage, safety and the unnvailability of a distribution system. These storage and safety problems have been discussed in the previous paragraphs. A further barrier to vehicular use is that individual state regulations tend to discourage experimentation with new fats.

A more detailed discussion of barriers and stimuli for hydrogen is contained in an attachment to Appendix I of "Hydrogen Tomorrow, Demands and Technology Requirements" (Reference 4). Tables 2,3 , and 4 are taken from Appendix $I$ of that document as being representative of early estimates of the relative severity of barriers in the trouble areas we have discussed.

\section{$2.4 \quad$ TECHNOLOGY}

\subsubsection{HYDROGEN PRODUCTION TECHNOLOGY}

Three methods of hydrogen production were considered in this study. The specific processes wh th are selected for analysis are considered to be representative of their generic types of the process. These processes are as follows:

(1) Hybrid therriochemical sulfur cycle process as a representative for thermochemical processes.

(2) Solid polymer electrolyte (SFE) water electrolysis as a representative for ad;anced electrolysis.

(3) Koppers-Totzek process as a representative for coal gasification. 
Table 2. Magnitude of Barriers to Utilization -- the Manufacture of Hydrogen: Tentative

Character fantions (from Reference 4)

\begin{tabular}{|c|c|c|c|c|}
\hline & & \multicolumn{3}{|c|}{ Barrlor: } \\
\hline & & $\begin{array}{l}\text { Requirae } \\
\text { Technologleal } \\
\text { Development }\end{array}$ & $\begin{array}{l}\text { Socletal and } \\
\text { Environmentul }\end{array}$ & Economle \\
\hline $\begin{array}{l}\text { (I) } \\
\text { (II) } \\
\text { (III) } \\
\end{array}$ & 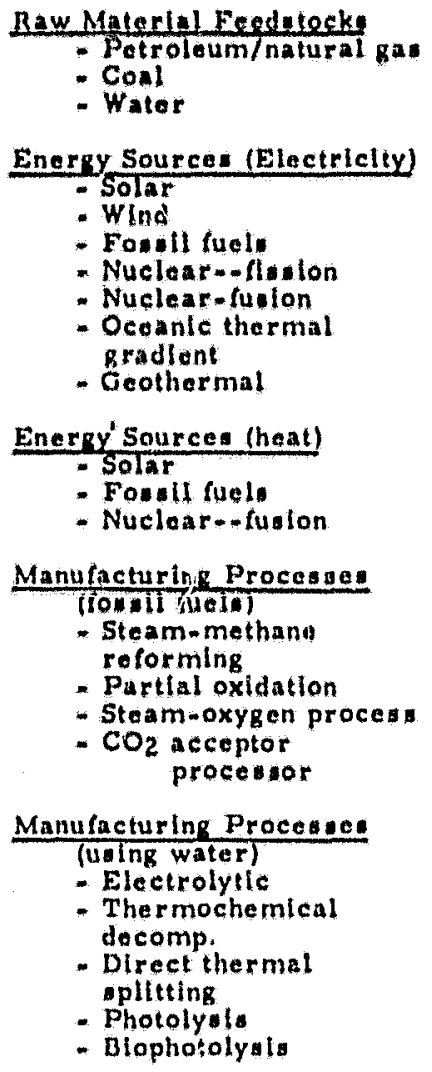 & $\begin{array}{l}\bullet \\
\bullet \\
: \\
\bullet \\
\bullet \\
0 \\
0 \\
\bullet \\
\bullet \\
\bullet\end{array}$ & $\begin{array}{c}1 \\
0 \\
0 \\
0 \\
0 \\
0\end{array}$ & 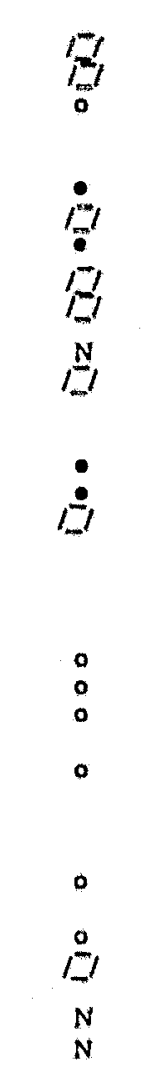 \\
\hline $\begin{array}{c}\text { Key } \\
\vdots \\
\square \\
0\end{array}$ & $\begin{array}{l}\text { Important barrlers to unage } \\
\text { The barrier to unage will re } \\
\text { Overcoming the barrier to u } \\
\text { Unknown. }\end{array}$ & $\begin{array}{l}\text { but these shoul } \\
\text { extenaive rese: } \\
\text { will require ma }\end{array}$ & $\begin{array}{l}\text { anonably eany } \\
\text { d Inveatlgation. } \\
\text { nputs to achieve }\end{array}$ & come. \\
\hline
\end{tabular}


Table 3. Eatimated Magnitude of Barriers to Utilizntion -. Transmission and Storage: Tentative Characterizations (Eron Reference 4)

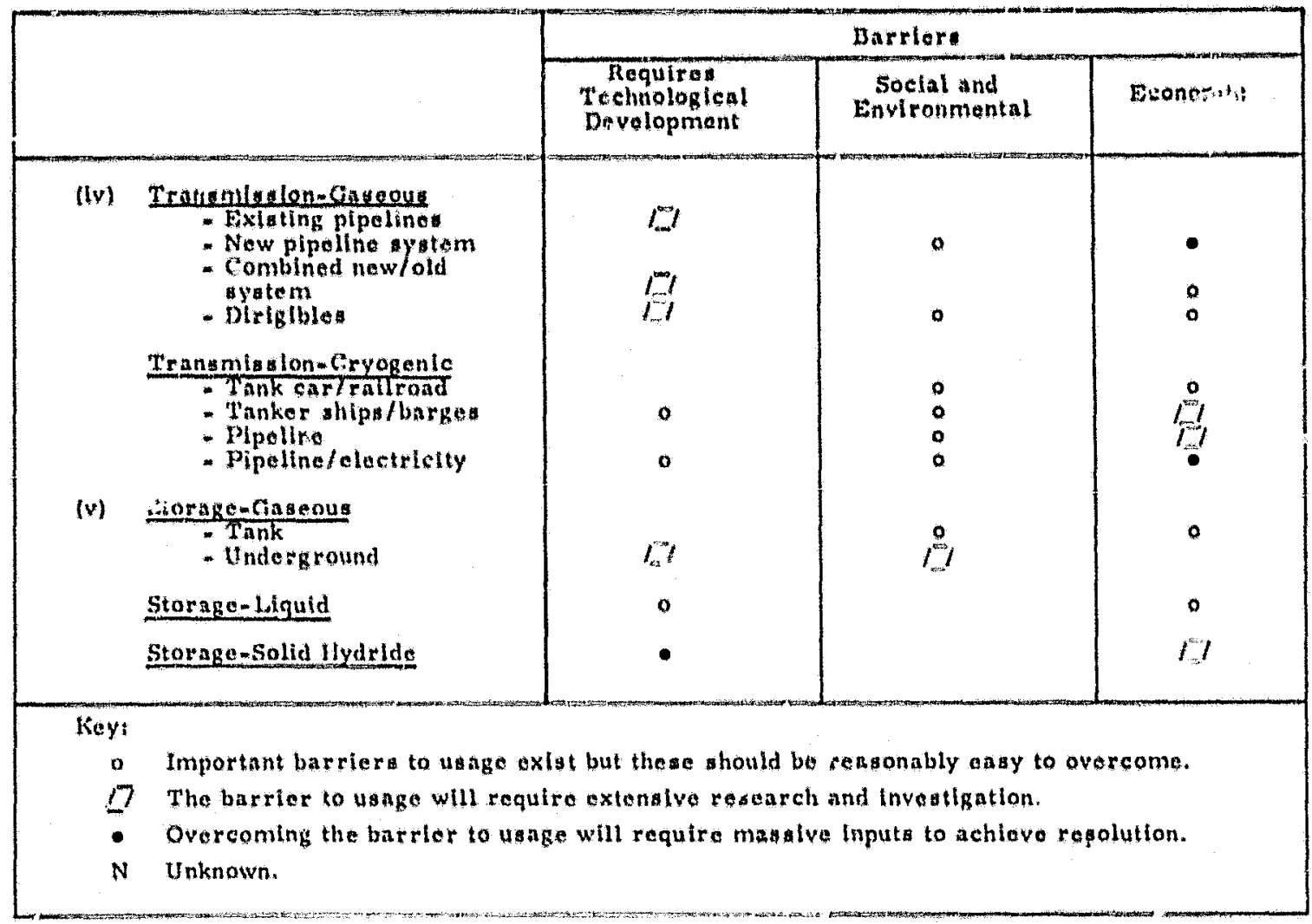


Table 4. Estimnted Magnitude of Barriers to Utilization -End Users: Tentative Characterizations

(from Reference 4)

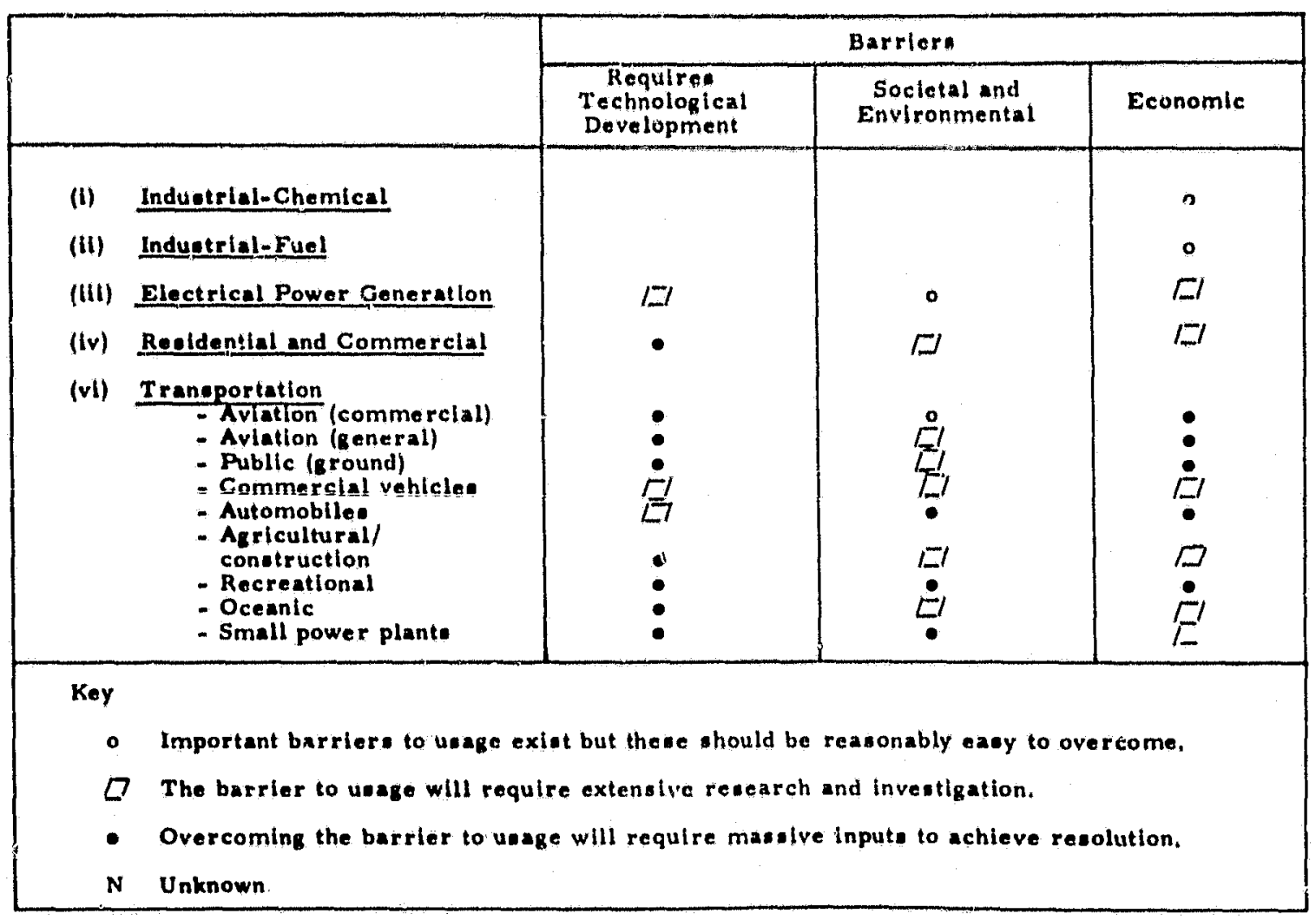


2.4.1.1 Thermochemical processes. There is no comnercial technology available for making hydrogen from water by the thermochemical process. Feveral process schemes are now at various stages of development. The Weatinghouse hybrid thernochemical sulfur cycle process lins been chosen as a representative for hydrogen production From thermochemienl procenses. This process apper. so be mere economical than alternative thermochemical hydrogen production systems.

The hybrid thermochemical sulfur cycles process, in its most general form, consists of two chemical reactions - one for producing oxygen and the other for producing hydrogen. The production of oxygen occurs via the thermal reduction of sulfur trioxide obtained from sulfuric acid.

$$
\mathrm{H}_{2} \mathrm{SO}_{4}+\mathrm{H}_{2} \mathrm{O}+\mathrm{SO}_{3}+\mathrm{H}_{2} \mathrm{O}+\mathrm{SO}_{2}+1 / 2 \mathrm{O}_{2}
$$

The equilibrium for Reaction 1 lies to the right at temperatures above $1000 K^{\circ}\left(1800^{\circ} \mathrm{R}\right)$ (Reference 5$)$. Catalysts axe available for accelenting the rate of sulfur trioxide reduction to sulfur dioxide and oxygen. The process is completed by using the sulfur dioxide from the thermal reduction step to depolarize the anode of a water clectrolyzer. The overall reaction occurring electrochemically is:

$$
2 \mathrm{H}_{2} \mathrm{O}+\mathrm{SO}_{2}+\mathrm{H}_{2}+\mathrm{H}_{2} \mathrm{SO}_{4}
$$

This is comprised of the individual renctions:

$$
\begin{aligned}
& \text { Cathode: } 2 \mathrm{H}^{+}+2 \mathrm{e}^{-}+\mathrm{H}_{2} \\
& \text { Anode: } \quad \mathrm{H}_{2} \mathrm{SO}_{3}+\mathrm{H}_{2} \mathrm{O}+2 \mathrm{H}^{+}+\mathrm{H}_{2} \mathrm{SO}_{4}+2 \mathrm{e}^{-}
\end{aligned}
$$

The net result of Reactions 1 and 2 is the decomposition of water into hydrogen and oxygen. Sulfur oxides are involved as reeycling intermediates. Although electrical power is required in the clectrolyzer, much smaller quantities than those necessary in conventional electrolysis are needed. The theoretical voltage to decompose water is $1.23 \mathrm{~V}$, with many comnereial electrolyzers requiting over $2.0 \mathrm{~V}$ (Reference 5). The power requirements for Reaction 2 ( 0.17 volts at unit activity for reactints and products s) thus appear to be theorexically less than 15 percent of those required in conventional electrolysis. This dramateally ehanges the heat and work required to decompose water and leads to improved thermal efficiencies.

The process is shown schematically in Figure 5. Hydrogen is generated electrolytically in an electrolysis celi which anodically oxidizes sulfurous acid to sulfuric acid while simultaneously generating hydregen at the cathode. Sulfuric acid formed in the electrolyzer is then vaporized using thermal energy from a high temperature heat source. The vaporited sulfuric acid (sulfur trioxide-steam mixture) flows to an indirectly heated reduction 
reactor where sulfur dioxide and oxygen are formed. Wet sulfur dioxide and oxygen flow to a separation system, where oxygen is produced as a process co-product and the suffur dioxide is recycled to the electrolyzer.

The cycle has the potential for achieving high thermal efficiencies while using common and inexpensive chemicals. The product hydrogen and oxygen streams are available under pressure and at high purity.

Developmental work on the hybrid thermochemical sulfur cycle process was started in 1973 by the Westinghouse Electric Corporation (Reference 5). The development program is based on the desire to have a process development unit (PDU), operating at the pressure, temperature, and performance levels desired for a commercial unit, in service by 1983 .

The development program is structured to solve various technological problems associated with the process steps in Figure 5 . The electrolysis tasks call for work on anodes, cathodes, membranes, catalysts, fabrication techniques, and cell performance over a growing scale from single cell atmospheric pressure test units.

The developnental areas related to the sulfuric acid vaporization step are completely dedicated to the evaluation of materials for the containment of high-pressure, high-temperature, boiling sulfuric acid.

In the area of oxygen generation, two tasks are being undertaken. One is to evaluate catalysts that promote the high-temperature reaction with the purpose of finding one that is economically optimum for the process; i.e., low cost, long life, and high activity. Several catalysts have already been evaluated; engineering judgment must await completion of the planned tests and economic trade-off studies to assess the impact of the alternate catalysts. The oxygen production step, operating at temperatures to about $870^{\circ} \mathrm{C}\left(1600^{\circ} \mathrm{F}\right)$, also requires a materials-evaluation task to determine suitable materials for containing very high temperature steam, $\mathrm{SO}_{3}, \mathrm{SO}_{2}$, and $\mathrm{O}_{2}$ on one surface, and a helium heat source fluid on the other.

The oxygen recovery, or separation, stage of the process requires engineering evaluation rather than development. Several processes can afford the required separations.

2.4.1.2 Advanced Electrolysis. Water electrolysis using alkaline electrolyzers has been in commercial use for many years for hydrogen production. Advanced electrolysis processes are under development to improve economics so that electrolysis can become a viable approach for producing large quantities of hydrogen on a commercial scale. Solid polymer electrolyte electrolyzer has been chosen as a representative for hydrogen production via advanced electrolysis of water. Solid polymer electrolyte electrolyzer appears to be more efficient than alternative electrolysis systems. 


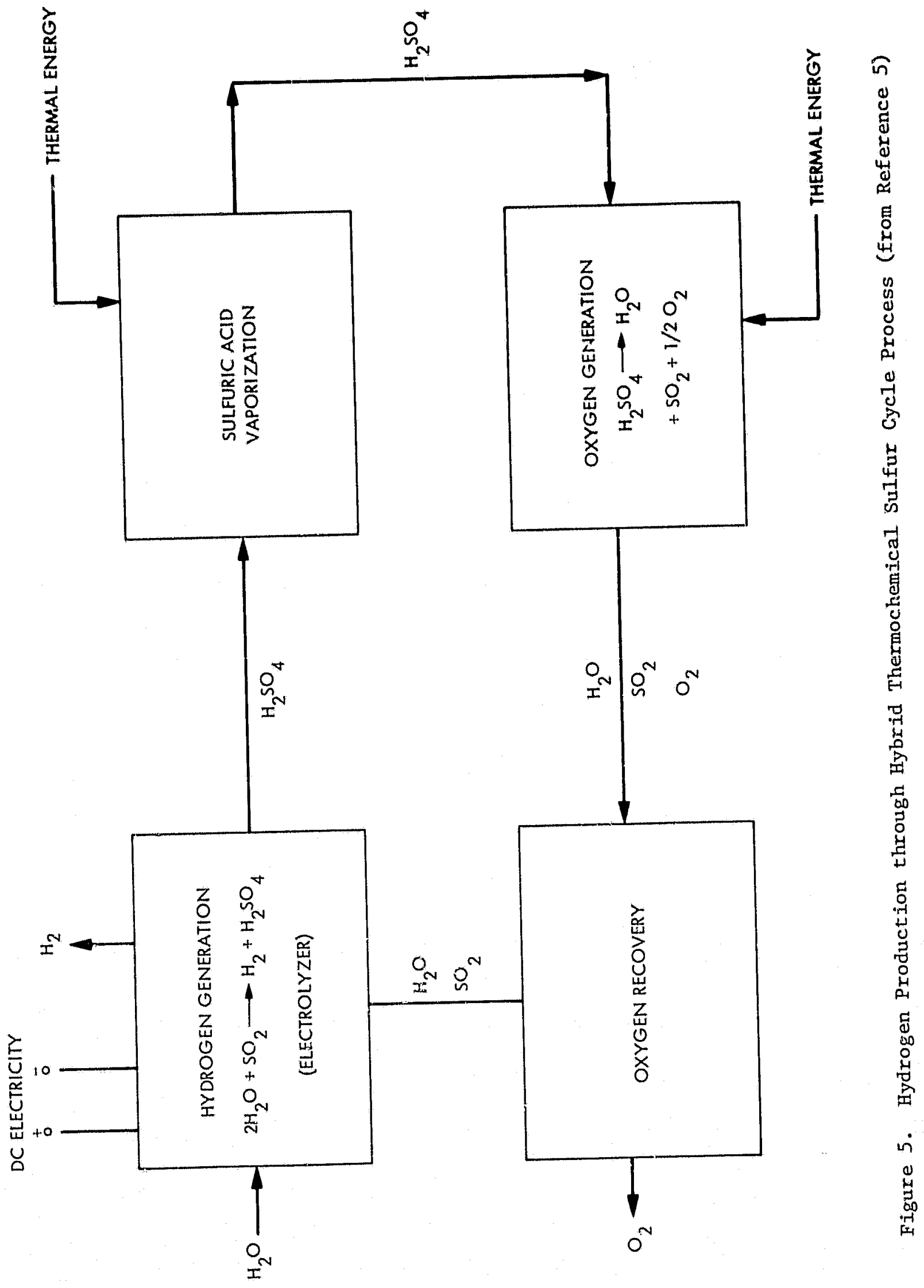


A solid polymer electrolyte (SPE) electrolyzer has been developed by General Electric Co., based on the solid polymer electrolyte (SPE) fuel cell technology. The SPE is a thin, solin, plastic sheet of perfluorinated sulfonic acid polymer which has nany of the physical characteristics of Teflon. Unlike Teflon, however. when a thin sheet of this material is saturated with water, the polymer becomes an excellent ionic conductor that provides low electrica! resistance. When it is used in an electrolysis cell, it is the only electrolyte required; there are no free acids or alkalis in the system. The electrolyte is attached mechanically to current collectors on each sife, and a voltage is applied across these collectors. At the negative electrode, hydrogen ions receive electrons to form hydrogen:

$$
2 \mathrm{H}^{+}+2 \mathrm{e}^{-}=\mathrm{H}_{2}
$$

while at the positive electrode, water is decomposed to form oxygen:

$$
\mathrm{H}_{2} \mathrm{O}=2 \mathrm{H}^{+}+1 / 2 \mathrm{O}_{2}+2 \mathrm{e}^{-}
$$

Ionic conductivity is provided by the mobility of the hydrated hydrogen ions $\left(\mathrm{H}^{+} \times \mathrm{H}_{2} \mathrm{O}\right)$, which move through the sheet of electrolvte by passing from one sulfonic acid group to another.

Use of the SPE results in the following advantages:

(1) Significantly higher cell efficiency than conventional electrolyzers, resulting in lower power consumption per unit of gas generated.

(2) Higher current density capability results in lower capital cost, size and weight for the electrolysis modules.

(3) The electrolyte is chemically bound in the polymer chain, resulting in a system with no free corrosive liquids to be concerned with during design, assembly, operation or maintenance of the system.

(4) Solid electrolyte simplifies the system design as well as improves reliability and safety.

There is a general belief that the SPE system will be substantially more expensive than more conventional alkaline systems because of the high cost of the membrane electrolyte and because of the large quantities of noble metal needed for the electrode catalys is and current collectors. However SPE may be able to operate at higher hydrogen production rates and higher efficiencies and compete in overall economies with the more conventional systems. 
The SPE development program for large scale hydrogen generation was initiated in 1975 and is planned to culminate in the demonstration of a $5 \mathrm{MW}$ system in 1983. The goals for this program are to achieve an overall efficiency of $90 \%$ with a system design capable of achieving, in production, a capital cost of $\$ 82 / \mathrm{kW}$ (Reference 6 ).

In order to achieve the above cost and efficiency goals, the technology development tasks are directed primarily at the following areas:

FOR LOWER COST

(1) Use low-cost materials for current collectors.

(2) Eliminate gasket seals.

(3) Use a lower-cost catalyst.

(4) Reduce catalyst loading.

(5) Use a lower-cost electrolyte.

FOR HIGHER EFETCIENCY

(1) Operate at higher temperatures (up to $150^{\circ} \mathrm{C}$ ).

(2) Improve catalytic electrodes.

(3) Optimize alectrolyte and cell design.

2.4.1.3 Coal Gasification. Many countries are now converting coal to hydrogen. Four processes (Koppers-Totzek, Winkler, Lurgi, and Wellman-Galusha) are commercially available for this purpose. Several other processes are being developed at the pilot-plant stage and will soon be ready for commercialization (Texaco, U-Gas, Babcock and Wilcox, Westinghouse, Combustion Engineering, and the Steam-Iron process).

A generalized process flow scheme for converting coal into hydrogen (from Reference 7 ) is shown in Figure 6 . Coal is gasified with steam and oxygen to produce a mixture rich in carbon monoxide and hydrogen. This mixture is purified using several downstream processing steps:

(1) A catalytic water-gas shift reaction uses carbon monoxide to produce additional hydrogen.

(2) Acid gas scrubbing removes carbon dioxide and hydrogen suifide.

(3) Catalytic methanation removes trace quantities of carbon monoxide. 


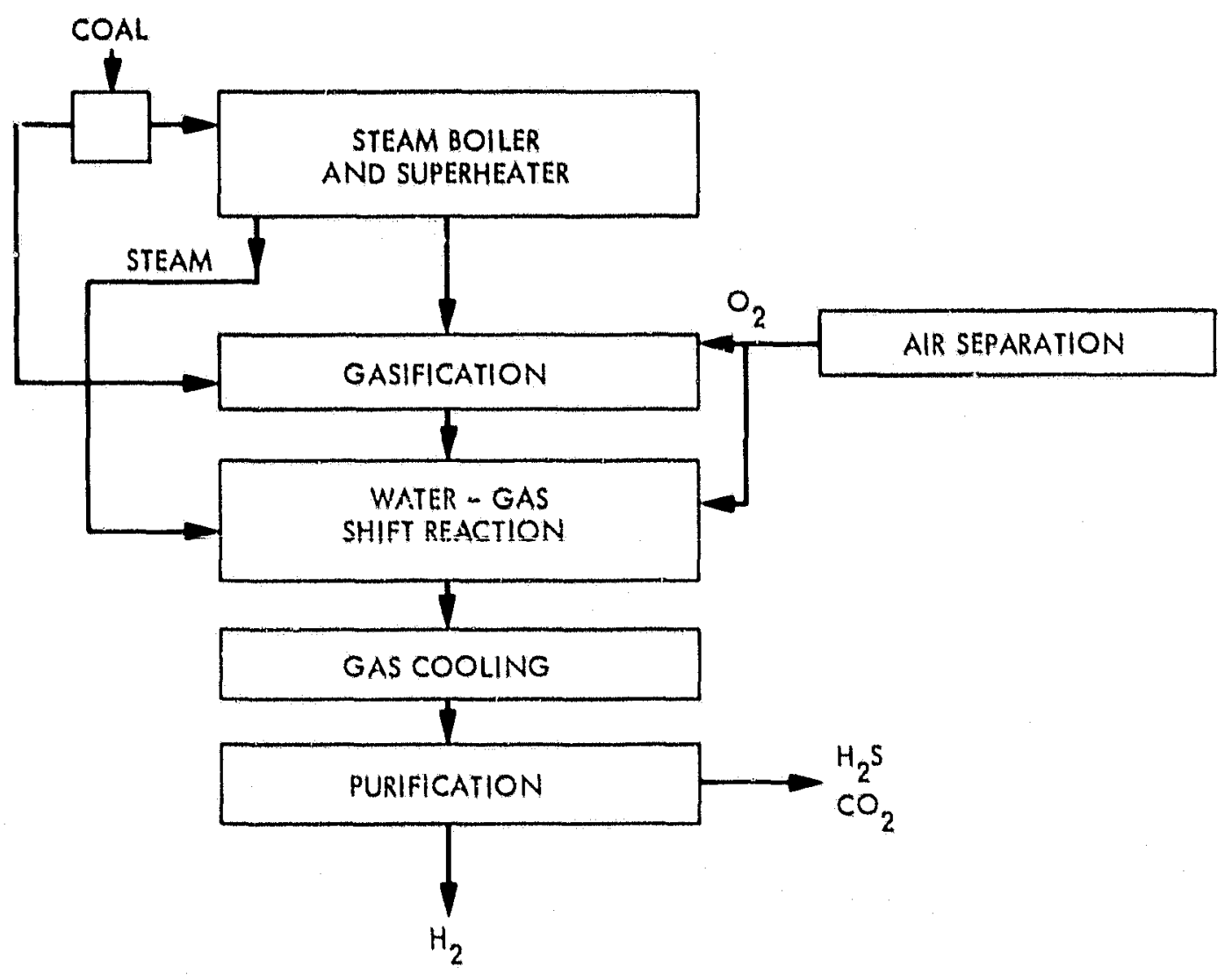

Figure 6. Generalized Process Flow Scheme for Converting Codl into Hydrogen (From Reference 7) 
Most of the processes gasify the coal at a high temperature to achieve high carbon conversion (usually above $90 \%$ ) and high concentrations of carbon monoxide and hydrogen in the raw product gas. A few processes operate at lower temperature and tend to produce some methane in the raw gas. In this case, the methane can be reformed downstream to produce additional hydrogen. The KoppersTotzek $(K-T)$ process which is extensively used for hydrogen production has been chosen as a representative in this study.

The Koppers-Totzek ( $K-T$ ) entrained slagging gasification process uses the rapid partial oxidation of pulverized coal in suspension with oxygen and steam. Reaction temperature at the burners is about $2000^{\circ} \mathrm{K}\left(3600^{\circ} \mathrm{R}\right)$, and as a result, no tars, cils, or condensable hydrocarbons are produced. Due to endothermic reactions and radiation, the gas exits the gasifier at approximately $1755^{\circ} \mathrm{K}$ $\left(3159^{\circ} \mathrm{R}\right)$. Gasifier pressure is slightly above atmospheric.

The K-T gasifier is a steam-jacketed, refractory-lined, carbon steel shell. A four-headed gasifier, which is capable of processing as much as $7.7 \times 10^{5} \mathrm{~kg}$ of coal per day, employs burners that are spaced $90^{\circ}$ apart. A two-headed gasifier design also exists that utilizes burners spaced $180^{\circ}$ apart and has about one-half the capacity of the four-headed version.

A wide variety of feedstocks, including tars, heavy oils, petroleum coke, char, and all ranks of coal can be gasified. The gas, rich in carbon monoxide and hydrogen, has a gross heating value of $1.12 \times 10^{7}$ Joules per cubic meter, on a dry basis. Characteris= tically, coal yields a gas consisting of $50-55 \%$ carbon monoxide and $30-35 \%$ hydrogen, both on a dry basis. Carbon dioxide, nitrogen, and sulfur compounds make up the balance. With 1 iquid feedstocks, the carbon monoxide and hydrogen are produced in an approximately equal volume of $45 \%$ each.

Figure 7 is a simplified flow diagram of the $\mathrm{K}-\mathrm{T}$ gasification system.

Coal is fed to the pulverization system where it is reduced to a size consistency of $70-90 \%$ minus 200 mesh, and is simultaneously drits to a moisture level of approximately $2 \%$. In general, however, the degree of drying depends on coal rank. Lignites, for instance are dried to $8 \%$. Wind-swept roller mills are used, and heat for drying is provided by burning a portion of the desulfurized fuel gas. Combustion gas used for drying is tempered to $700-755^{\circ} \mathrm{K}\left(1260-1359^{\circ} \mathrm{R}\right)$ to keep coal particulate temperature at $355^{\circ} \mathrm{K}\left(630^{\circ} \mathrm{R}\right)$ to prevent devolatilization. Pulverized coal is transported pneumatically with nitrogen and stored under an ineri atmosphere. All vent lines lead to bag filters which prevent dust emissions. The pulverized coal is conveyed from storage to the service bins (two at each 4-headed gas fier) each of which in turn feeds a pair of feed bins. From each feed bin the coal is metered by two feed screws into a mixing zone, where it is entrained in a premixed stream of steam/oxygen and fed into the gasifier. 


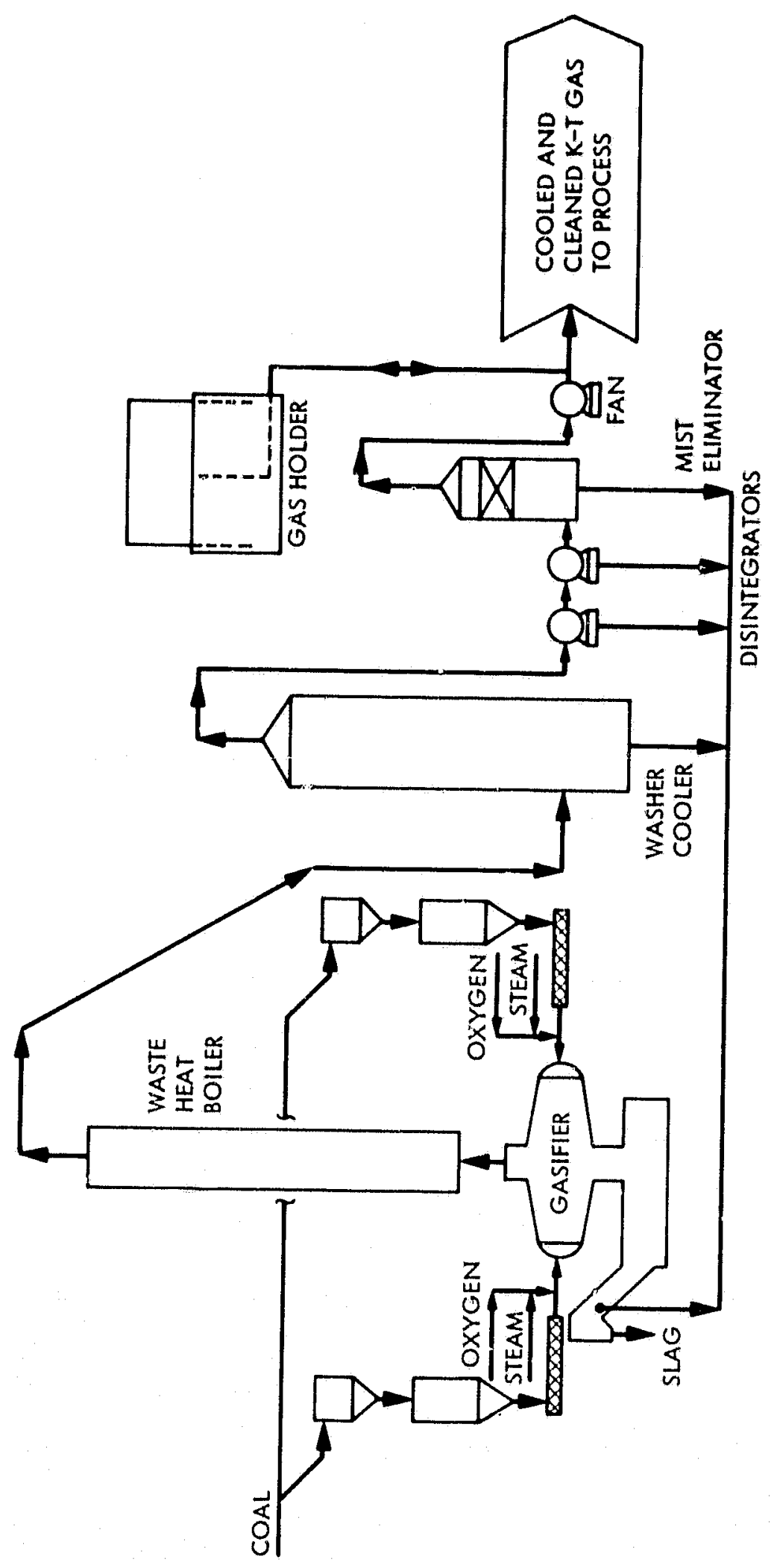

告 
About $50 \%$ of the conl ash leaves the gasifier through the bottom in molten form and is then solidified by contact with water in a quench tank situated beneath the gasifier. The ash is removed from the quench tank by means of a scraper-conveyor assembly and then conveyed to a slag storage bin which permits loading of the slag inth railroad cars for disposal at the mine site.

The remaining ash, along with any ungasified carbon, is entrained with the gas that leaves the top of the gasifier, and is sprayed with water, if necessary, to freeze any slag droplets prior to entry into the waste-heat boiler. High-pressure saturated steam is generated in the waste-heat boiler, and gas leaving the economizer section is directed to a washer-cooler wherein the gas is cooled by spray water, typically to about $310^{\circ} \mathrm{K}\left(558^{\circ} \mathrm{R}\right)$, while about $90 \%$ of the entrained particulates are simultaneously removed. Gas then enters Theisen-type irrigated disintegcators to reduce the dust load of the gas to about 0.07 grains per standard cubic meter. After passing through a mist eliminator, the gas is moderately boosted in pressure by a fan to overcome downstream pressure losses. Recirculating cooling tower water is used in the cleaning system, and the solids are recovered in a clarifier used in combination with a Filtration system. A filter cake is conveyed to a bin for loading into railroad cars,

Gas leaving the fan at each gasifier is manifolded into the suctions of three gas compressors which deliver the gas at $1.24 \mathrm{x}$ $10^{6} \mathrm{~N} / \mathrm{m}^{2}$ to the acid gas removal system. A short-residence time gas holder is provided at the compressors' suction header For control purposes.

The acid gas removal facilities are comprised of three parallel strings, each of which consists of a cos hydrolysis colum followed by an absorber. Within the cos hydrolysis column, the gas is combined with hot circulating methyldiethanolamine (MDEA) solution to promote hydrolysis of $\cos$ to $\mathrm{H}_{2} \mathrm{~S}$ in order to facilitate a high degree of sulfur removal within the absorber. Acid gases are stripped from the MDEA absorbent and sent to two multi-state claus units, each complete with a tail gas unit, for recovery of elemental sulfur. Recovered sulfur is stored in molten form and loaded into railroad tank cars.

Gas leaving such an $\mathrm{H}_{2} \mathrm{~S}$ absorber contains approxinately $115 \mathrm{ppm}$ of $\mathrm{H}_{2} \mathrm{~S}$ plus $\mathrm{COS}$, or 35 grams of $\mathrm{SO}_{2}$ equivalent per million Btu of gross calorific heat content of the fuel gas.

Gas from each $\mathrm{H}_{2} \mathrm{~S}$ absorber is sent to one of three drying columns for removal of water to meet a $245^{\circ} \mathrm{K}$ ( $441^{\circ} \mathrm{R}$ ) gas dew point so as to permit long distance transmission. Drying is effected by using recirculating triethylene glycol (TEG). Water is removed from the TEG by distillation using iso-octatie as an azeotroping agent. Product gas, having a gross heating value of $1.12 \times 107$ Joules per standard cubic meter, leaves each drying column at approximately $11.7 \times 106 \mathrm{~N} / \mathrm{m} 2$, and then enters the gas distribution system. 
Prior to the gas drying columns, a portion of the desulfurized gas is piped through the gasification plant for use in coal drying, sulfur recovery, and for the firing of two auxiliary boilers. The auxiliary boilers are provided to superheat steam from the gasifier waste heat boilers, and also to evaporate and superheat additional feedwater, thereby providing sufficient steam to meet the demands of the gasification plant. All major compressors, except for the three oxygen compressors and one of the four air compressors at the four air separation plants, are equipped with steam turbine drives to keep the amount of purchased electrical power to a minimum, while still allowing a practical means of starting the plant.

Blowdown from all cooling towers, along with blowdown from the steam distribution system, is treated to mect acceptable stream standards. Principally, the treatment involves destruction of HCN and $\mathrm{NH}_{3}$ (which are present in small quantities in aqueous blowdown from the cleaning system) by chlorination, dechlorination, and pll ad iustment.

\subsubsection{STORAGE, TRANSMISSION, AND DISTRIBUTION OF HYDROGEN}

Storage, transmission and distribution are essential

factors in all aspects of hydrogen utilization except for those applications where the hydrogen is produced and quickly transformed into an end product within a continuous process cycle. Local networks for storage and distribution of low-pressure manufactured gas (producer or coal gas - a mixture of hydrogen and other gases) existed in several countries, including the United states, around the curn of the century and some are still in use in many parts of the world supplying gas for commercial and residential illumination, heating and cooking. With the advent of cheap natural gas, these networks in the United States were converted to other uses and the gas production Eacilities were abandoned. If hydrogen is to achieve a significant energy role by supplanting our diminishing supply of natural gas and other fossil fuels, this trend must be reversed, with the present networks converted to distribute hydrogen or hydrogen mixtures. Future hydrogen production facilities will require transmission and distribution networks which would include the capability to store large quantities of hydrogen at both the source and the terminal ends of the transmission links and the capability to provide, on demand, hydrogen to network customers.

2.4.2.1 Storage Methods. There have been very few changes in the methods for storing hydrogen in the past 10 years. With the exception of the aerospace-related improvements and enlargements in the storage containers for liquid hydrogen to $103 \mathrm{M}$ pascals $(15,000 \mathrm{psig})$, the commercial practices in the United states for storing hydrogen have not changed significantly.

The following paragraphs are devoted to a discussion of some of the methods for storing hydrogen. 
Gaseous hydrogen is conventionally stored in banks of " $K$ " bottles and "tube" tanks at pressures as high as $41 \mathrm{M}$ pascals $(6000$ psig). For special applications, "tube" tanks have been fabricated and utilized at pressures as high as $70 \mathrm{M}$ pascals $(10,000 \mathrm{psig})$. These tanks are fabricated from a low-carbon steel, typically Type 4130, with a piercing technique which results in a "seamless" (nonwelded) heavy-wall tube, The tube ends are subsequently swaged closed and appropriate machining provides ports for tank manifolding and component installation. The levelo at which these "seamless" tanks are stressed during operation are well below the yield strength of Type 4130 steel and appear sufficiently low to preclude any problems arising from interactions with the high-pressure gaseous hydrogen that they contain.

Larger quantities of gaseous hydrogen are stored in welded, laminated-wa1l, pressure vessels at pressures as high as $103 \mathrm{M}$ pascals $(15,000 \mathrm{psig})$. This vessel design incorporates a liner ir inner lamina of austenitic stainless steel or mild steel to provide compatibility with the high-pressure hydrogen and outer laminae of high-strength steel which provides the capability for containment of the high-pressure hydrogen (Reference 8 ).

\section{UNDERGROUND STORAGE}

Underground storage of hydrogen is a possibility in depleted petroleum reservoirs and aquifers similar to those used by the natural gas industry or in man-made caverns (containers) formed by the leaching (solution-mining) of cavities in salt deposits or by other low-cost construction techniques. It would be a significant economic advantage over the present method of storing gaseous hydrogen in containers at high pressure.

It has been reported that, for a time, Gaz de France was injecting about $20 \times 10^{6}$ cubic meters ( $706 \times 10^{6}$ cubic feet) per year of hyarogen-rich refinery byproduct gas into an aquifer structure near Beynes, France. No problems were encountered during this operation, which was halted only when the byproduct gas was no longer available. Gaz de France has converted this aquifer to the storage of natural gas and is in the process of recovering much of the hydrogen-rich gas by displacing it with natural gas. A surprisingly sharp interface between the two gases is maintained as the natural gas sweeps from one side to the opposite side of the aquifer structure.

A new technique has been reported that involves underground storage of $95 \%$ purity hydrogen in solution-mined salt caverns at a nominal pressure of $5 \mathrm{M}$ pascals (750 psig). It has been developed and is being utilized by the Imperial Chemical Industries (ICI), Ltd., at their Teesside facility in England (Reference 9). Three caverns are operated in a "wet" mode using saturated brine to utilize the available space in these man-made caverns more efficiently. The brine from the caverns is displaced by pressurized hydrogen and is stored in surface ponds until needed to displace the 
stored hydrogen. Surface pend brine is then pressurized to a level slightly above the pressure of the stored hydrogen and used to displace the hydrogen from the caverns. Below the surface, at a depth of 365 meters (1200 feet), the storage system can operate on a pressure differential of $0.4 \mathrm{M}$ pascals ( $50 \mathrm{psig}$ ) in addition to the static head of the brine. The brine must be maintained at a saturated level to prevent additional leaching of the caverns, and the brine temperacure is controlled to ensure that the cavern walls are not damaged by thermal shock. When the caverns are filled with hydrogen, the facility "stores" the surplus hydrogen as cyclohexane rather than disposing of it by flaring.

\section{HYDROGEN STORAGE IN METAL HYDRIDES}

Although the concept has not achieved commercial recognition, experimental and prototype metal hydride storage containers have been built and are being operated on a limited scale by several organizations. Srorage of hydrogen as a hydride at local ambient temperature and pressure solves some of the prablems associated with gaseous or liquid storage but many new problems peculiar to hydride storage must be addressed before this storage technique can achieve widespread popularity.

Relatively high-density storage of hydrogen as a metallic hydride eliminates the necessity to store and control high-pressure hydrogen gas and offers a significant reduction in container volume and some reduction in container weight. Although thermal control is required to remove heat when the hydride container is being charged with hydrogen and to supply heat for discharging, this control is minimal when compared to that involved with the liquefaction and storage of hydrogen at cryogenic temperature.

The Brookhaven National Laboratory (BNL) has conductod an extensive program using iron titanium (FeTi) hydride which is representative of the present practice for hydride storage. The advantages of FeTi hydride are relatively low cost, low disassociation pressure and a moderate operating temperature. The disadvantages are its weight, which limits applications, and its sensitivity to contaminants (water, oxygen, etc.) which requires the use of ultrapure hydrogen.

The Billings Energy Corporation of provo, Utah, has also been corducting research with FeTi hydrides in prototype containers (Reference 10). Several mobile and stationary, applications are being investigated. To date, the Billings Energy Corporation has converted three cars, two buses and a small tractor to operate with hydrogen as a fuel. Plans for expansion of hydride utilization from prototype to a limited commercial scale are in progress, with proposals for vehicle fleet (buses, taxicabs, etc.) conversions and for additional homes which will be built near the "Hydrogen Homestead."

Daimler-Benz A.G. of West Germany reportedly has converted a passenger van to operate on hydrogen which is delivered from FeTi hydride containers (Reference 11 ). In this conversion, Daimler-Benz 
also cools (air conditions) the ambient air in the passenger compartment by passing the inconing air around the hydride tank where heat is transferred to the hydride for discharging the hydrogen for engine operation.

The University of Denver at Denver, Colorado, and the Frgenics Division of MPD Technology Corporation in Waldwick, New Jersey, have been investigating hydrides of the rate earth metals and nickel with potential applications in lightweight containers and for powering of vehicles which are used in enclosed areas (fork lifts, tunneling devices, etc.) with non-polluting hydrogen.

A:gonne National Laboratory has also been working with rare earth metal hydrides; the Argonne HYCSOS concept uses two different hydrides to store and recover thermal energy for heating, cooling, and energy conversion in an integrated system.

\section{STORAGE OF LIQUID HYDROGEN}

The storage of liquid hydrogen in evacuated double-wall insulated containers provides an acceptable low loss rate, especially when integrated with a device which will periodically demand enough hydrogen to utilize the "boil-off" gas which would normally be flared. Experience has shown that the larger the storage container, the smaller the percentage of stores hydrogen that is lost by "boil-off".

2.4.2.2 Transmission. Large quantities of hydrogen in the United states are shipped as liquid hydrogen in evacuated, double-wall, insulated containers which have been mounted on trailer trucks, railway cars, or barges. Smaller quantities of hydrogen are shipped as a compressed gas in "tube" tanks which are mounted on truck trailers and in " $K$ " bottles which can be delive'red either singly or manifolded on pads.

The longest history of the successful pipeline transmission of hydrogen on a commercial scale is reported to be by the Chemishe Werke Huls $A G$ network, which has been in operation in the Ruhr Valley of West Germany since 1938. This underground pipeline network is about 210 kilometers ( 130 miles) long with pipe sizes fr, 15 to 30 centimeters ( 6 to 12 inches). The network handles $95 \%$ pur: $y$ hydrogen at a pressure of $1.5 \mathrm{M}$ pascals $(225 \mathrm{psig}$ ) with four separa injection points and nine separate users of hydrogen. There are int intermediate compressors or storage vessels, and the system operates at a nearly constant pressure from linepack achieved by piston-type compressors for the electrolytic hydrogen and discharged hydrogen from the pyrolysis producer at normal operating pressure. No significant problems have been encountered during 30 years of pipeline operation, which supports the premise that a properly designed hydrogen pipeline operaced with appropriate precgutions is no more dangerous than a natural gas network. 
If hydrogen utilization is to achieve any significance as an energy alternative to the decreasing supply of natural gas, lower cost and more efficient transmission methods must be utilized. The preferred nethod would be to transmit bulk gaseous hydrogen through a pipeline network similar to that presently in use for natural gas, and preliminary evaluations indicate that this concept is feasible. Two approaches should be crnsidered:

(1) Modification of existing natural gas pipelines by increasing the compressor size. This would be the most cost-effective plan for achieving a bulk hydrogen transmission network. Some penalty in allowable operating pressure would be necessary to account for the debilitating effect that hydrogen has on most metals.

(2) Installation of new pipelines which are specially designed for hydrogen transmission. With appropriate materials, line sizes and components, transmission costs will be minimized and operaticnal safety will be enhanced.

The probability of long-distance pipeline transmission of liquid hydrogen is remote. The cost of the double-wall insulated pipe used to prevent heat input from the surroundings would be prohibitive unless the transmission could be coupled with another benefit such as the energy pipe. The energy pipe concept requires a cryogenic temperature low enough to achieve superconductivity in the material which is conducting electrical power. Liquid helium is presently being used for laboratory-scale investigations of this power transmission concept, but some materials exhibit superconductivity in the temperature range of liquid hydrogen. If the transmission of hydrogen and electrical power through the same pipe is feasible, this practice for iiquid hydrogen sransmission could achieve some significance.

2.4.2.3 Distribution. Almost all of the "merchant" hydrogen that is sold to dispersed customers is transported by truck to the customer's facility.

In preparation for the anticipated utilization of hydrogen or mixtures of hydrogen and other gáses in residences and industries as a substitute fuel for the presently-utilized natural gas, several preliminary investigations have been conducted to explore the ramifications of such an occurrence. Ideally, the present natural gas distribution network and appliances would continue in service with only minor modifications or adjustments to convert them to hydrogen usage.

The Public Service Electric and Gas Company of Newark, New Jersey, has determined that present appliance burners are satisfactory for an $80 / 20$ mixture of natural gas and hydrogen. Any mixture with more than $20 \%$ hydrogen will probably require burner replacement with burners designed to function properly with the anticipated hydrogen 
level. GASCO, a Hawaiian utility, manufactures and distributes gas in Honolulu, Hawaii, which is a mixture of about $90 \%$ methane and $10 \%$ hyl' ogen. This manufactured gas is used in standard natural gas appliances with no apparent problems (Reference 12).

\section{$2.5 \quad$ ECONOMICS OF HYDROGEN PRODUCTION}

\section{5 .1 HYDROGEN FROM COAL}

Estimated costs of hydrogen production, based on 1978 dollars, using the $K-T$ gasification process are presented and discussed in the following paragraphs. These estimated costs were based on data presented by the Koppers Company (Reference 7), and no attempt was made to estimate increases in labor costs and capital equipment costs that probably will occur between the 1978 time frame and the time at which contracts for such a plant are made and the plant is constructed. However, they do include monies for the interest on capital during the construction period, which will last from three to four years. The capital cost presented by the Koppers Company was estimated for a fully-integrated plant for the production of 100 million SCFD of hydrogen. This cost was pro-rated for a 380 million SCFD plan using line following formula:

$$
\begin{aligned}
& c_{1}=\left(c_{2}\right) \times\left(\frac{z_{1}}{z_{2}}\right) \\
& c=\text { Capital Cost of plant } \\
& z=\text { plant Size }
\end{aligned}
$$

A scenario using U.S. coal prices provided the basis for calculating hydrogen production costs via the $\mathrm{K}-\mathrm{T}$ process.

The product-gas from the plant contains $94.7 \%$ hydrogen which is available at a pressure of $500 \mathrm{psig}$. The basic assumptions in hydrogen production costs via the $\mathrm{K}-\mathrm{T}$ process include a $75 \%$ debt at $9 \%$, a $25 \%$ equity at $12 \%$ discounted cash flow rate of return, a 20 year project life, and a $50 \%$ tax rate.

The economics of hydrogen production using the $\mathrm{K}-\mathrm{T}$ process are given in Table 5. The production cost of hydrogen in 1978 dollars in a fully-integrated plant will be about $5.25 \$ / G J\left(5.51 \$ / 10^{6} \mathrm{Btu}\right)$ based on a coal price of $1.14 \$ / G J\left(1.2 \$ / 10^{6} \mathrm{Btu}\right)$ in the year 1985. Figure 8 presents the sensitivity of the cost of hydrogen production to the cost of coal.

\subsubsection{HYDROGEN FROM THERMOCHEMICAL SPLITTING OF WATER}

The estimated costs of hydrogen production via the Hybrid Thermochemical sulfur Cycle plant using a dedicated high-temperature gas-cooled reactor (HTGR) and based on 1978 dollars are presented and 
Table 5. Cost of Hydrogen from Coa1 Gasification (1978 Dollars)

\begin{tabular}{|c|ccc|c|}
\hline \multirow{2}{*}{ Year } & \multicolumn{3}{|c|}{ Coal Price } & Hydrogen Production Cost \\
\cline { 2 - 5 } & $\$ / G J\left(\$ / 10^{6} \mathrm{Btu}\right)$ & $\$ /$ ton & $\$ / G J\left(\$ / 10^{6} \mathrm{Btu}\right)$ \\
\hline 1985 & $1.14(1.2)$ & 29.7 & $5.25(5.51)$ \\
\hline \multirow{3}{*}{2005} & $1.24(1.3$ & 32.2 & $5.26(5.53)$ \\
& $1.7(1.8)$ & 44.63 & $6.09(6.39)$ \\
& $1.9(2.0)$ & 49.6 & $6.42(6.74)$ \\
\hline \multirow{3}{*}{2025} & $1.05(1.1)$ & 27.27 & $4.93(5.12)$ \\
& $1.7(1.8)$ & 44.63 & $6.09(6.39)$ \\
& $3.33(3.5)$ & 86.78 & $8.9(9.35)$ \\
\hline
\end{tabular}

Process assumed: Koppers-l'ot 4 ek $(K-I)$ for 1985 ; Improved $K-I$ process for 2005 and 2025. These plants are fully integrated (producing required electridaty on stee).

Overall plant efficlency: 0.535 (1985); 0.576 (2005 and 2025)

Plant Capacity: $10.76 \times 10^{6} \mathrm{~m}^{3} /$ day $\left(380 \times 10^{6} \mathrm{ft}^{3} /\right.$ day $)=130 \times 10^{12}$

$\mathrm{J} /$ day $\left(123.5 \times 10^{9} \mathrm{Btu} / \mathrm{day}\right)$

Total. Plant Investment: $839.5 \times 10^{6}$ dollars

Hydrogen Purlty: $97.4 \%$

Coal Price: U.S. Coal price scenario for electric utilities from JPL reference scenario 


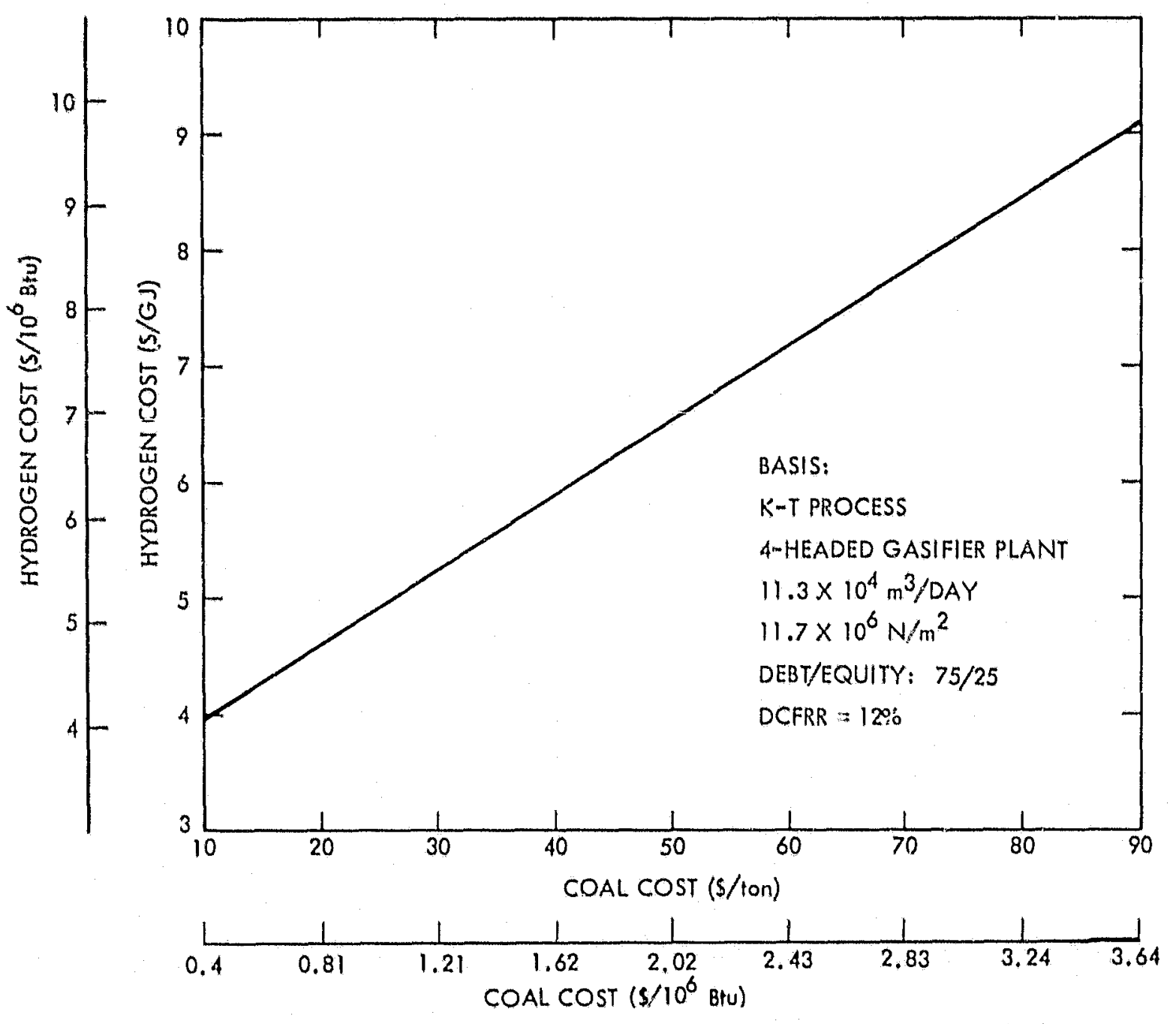

Figure 8 . Sensitivity of Hydrogen Production Costs to Coal Cost 
discussed in the following paragraphs. These estimates were based on cost data presented by the Westinghouse Electric Corporation, developer of the process (Reference 5).

The evaluation here considered utility Financing, an $18 \%$ annual charge on depreciating investment, an $80 \%$ capacity factor, and no credit for the oxygen produced.

The total plant investment for a hybrid thermochemical sulfur cycle plant using a dedicated high temperature gas-cooled reactor (HTGR) shown in Table 6 includes the direct costs of the hydrogen production plant and of the HTGR heat source. The non-depreciating assets are land and land rights, and these are shown separately from the other direct costs for the purposes of evaluation. The special materials under depreciating assets comprise the initial supply of coolant, chemicals, catalysts, Iubricants, and other materials needed for operation of the overall plant. A contingency of $20 \%$ is applied to both the hydrogen generation facilities and the IITGR physical plant.

Indirect costs shown in Table 6 are expense items of a general nature which apply to the overall project of building an operable plant, rather than to one of direct costs. These costs, except for interest rates during construction, were not estimated in detail but were calculated as a percentage of the direct cost.

The hydrogen production cost is given in Table 7 and is made up of the contributions of non-depreciating and depreciating capital, operation and maintenance, and nuclear fuel cycle costs. These are calculated on an annual basis. The annual charge on non-depreciating assets, e.g., land, is assumed to be ten percent. The charge on depreciating assets is $18 \%$. An $80 \%$ capacity factor was assumed. IEA $R$ D and $D$ strategy project price assumptions for uranium are used as nuclear fuel cost for the plant and no credit is taken for the oxygen produced.

Figure 9 shows the hydrogen production cost plotted against nuclear fuel cost. It is interesting to note that doubling the nuclear fuel cost, the hydrogen production cost increases by only $25 \%$ for the worst voltage case $(0.8 \mathrm{~V})$ due to high capital intensity of this process.

\section{$2.5 .3 \quad$ HYDROGEN FROM WATER ELECTROLYSIS}

Estimated costs of hydrogen production via the solid Polymer Flectrolyte (SPE) electrolyzer are presented and discussed in the following paragraphs for each of two conditions:

(1) On-site small-scale electrolyzer buying electricity.

(2) Large central electrolyzer using a dedicated High Temperature Gas-Cooled Reactor (HTGR). 

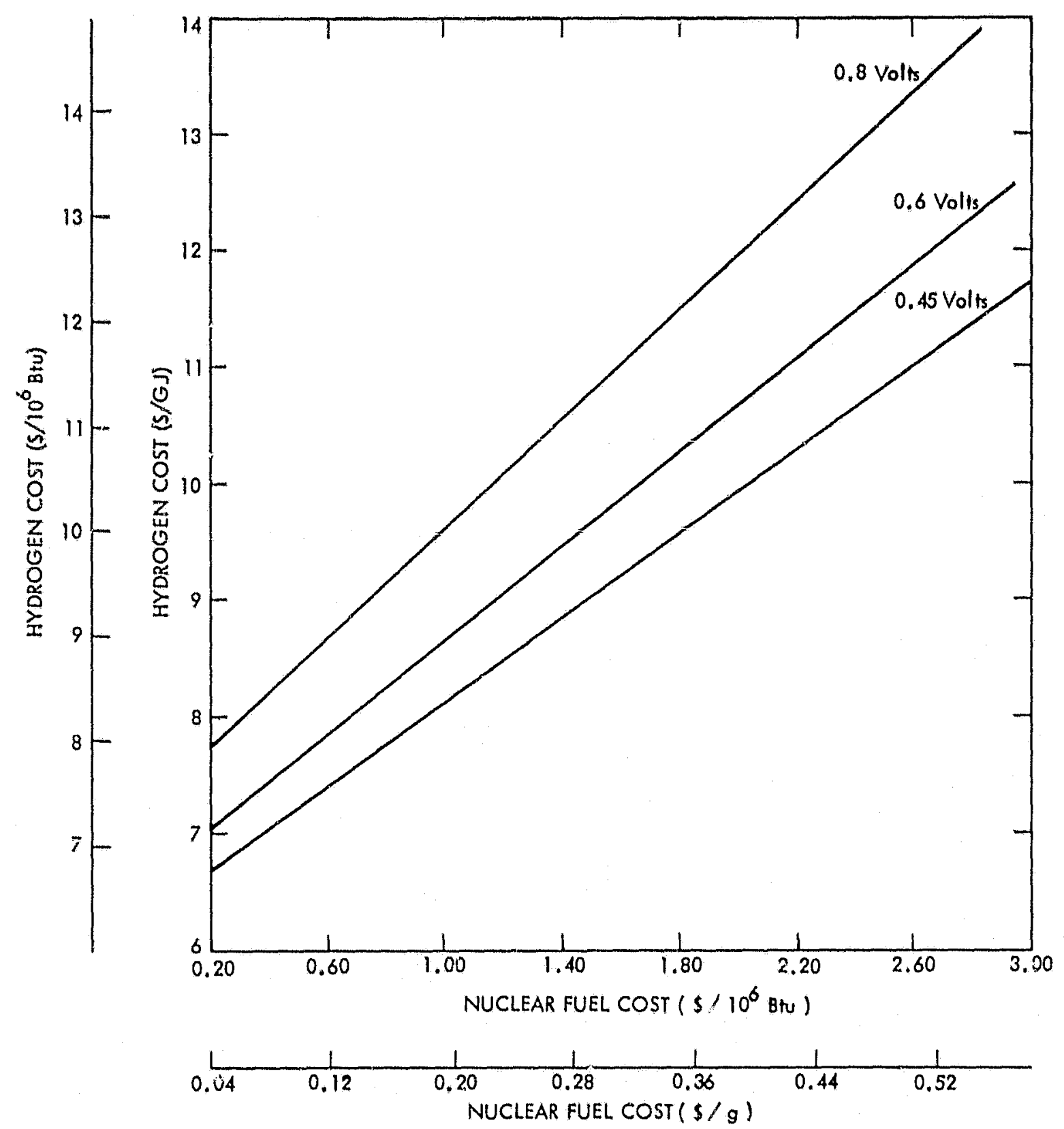

Figure 9. Sensitivity of Hydrogen Production Costs to Nuclear Fuel Cost for Hybrid Thermochemical Sulfur Cycle Plant using a Dedicated HTGR 


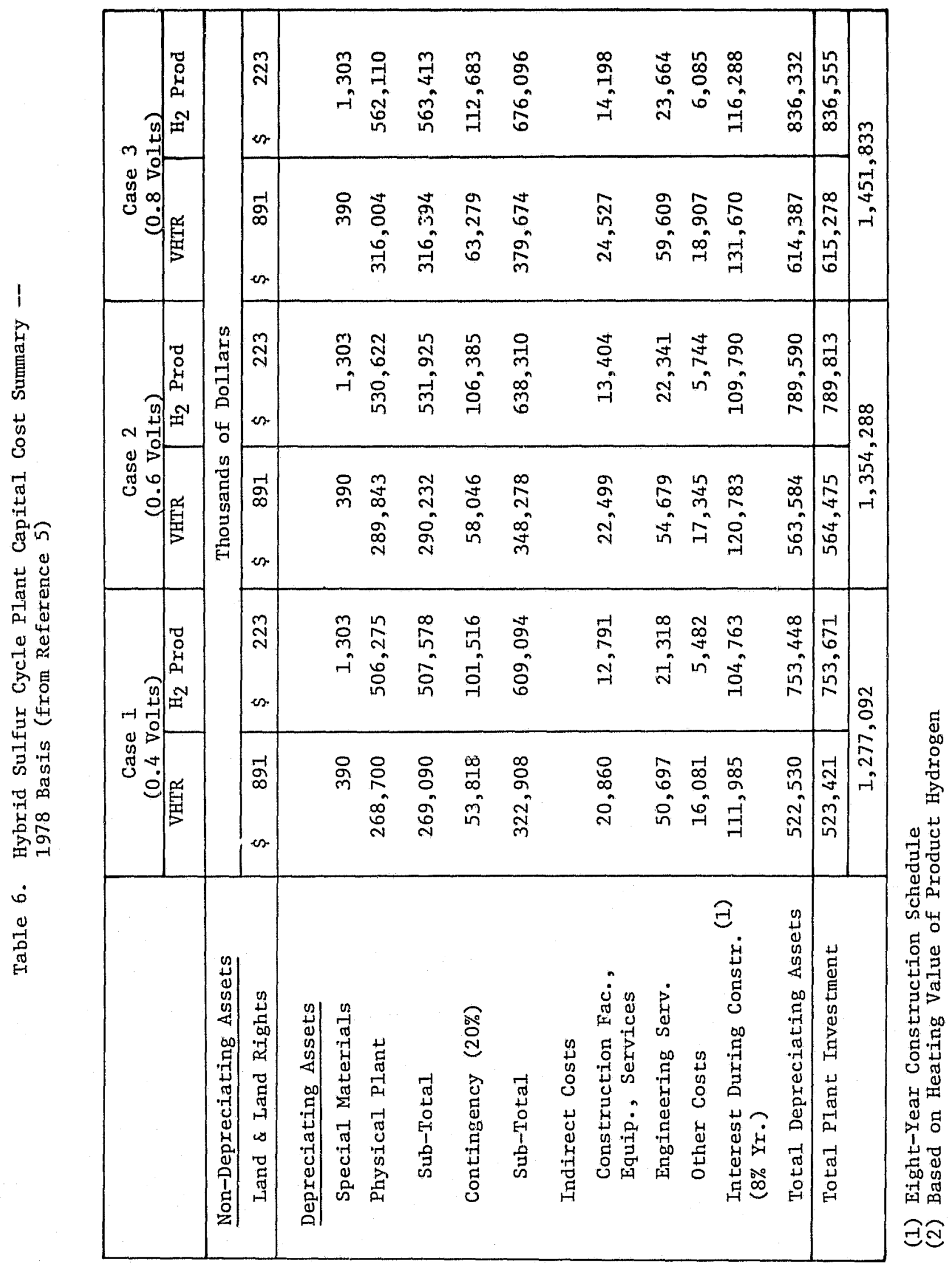


Table 7. Cost of Hydrogen from Hybxid Thermochemical

Sulfur Cycle plant (1978 Doliars)

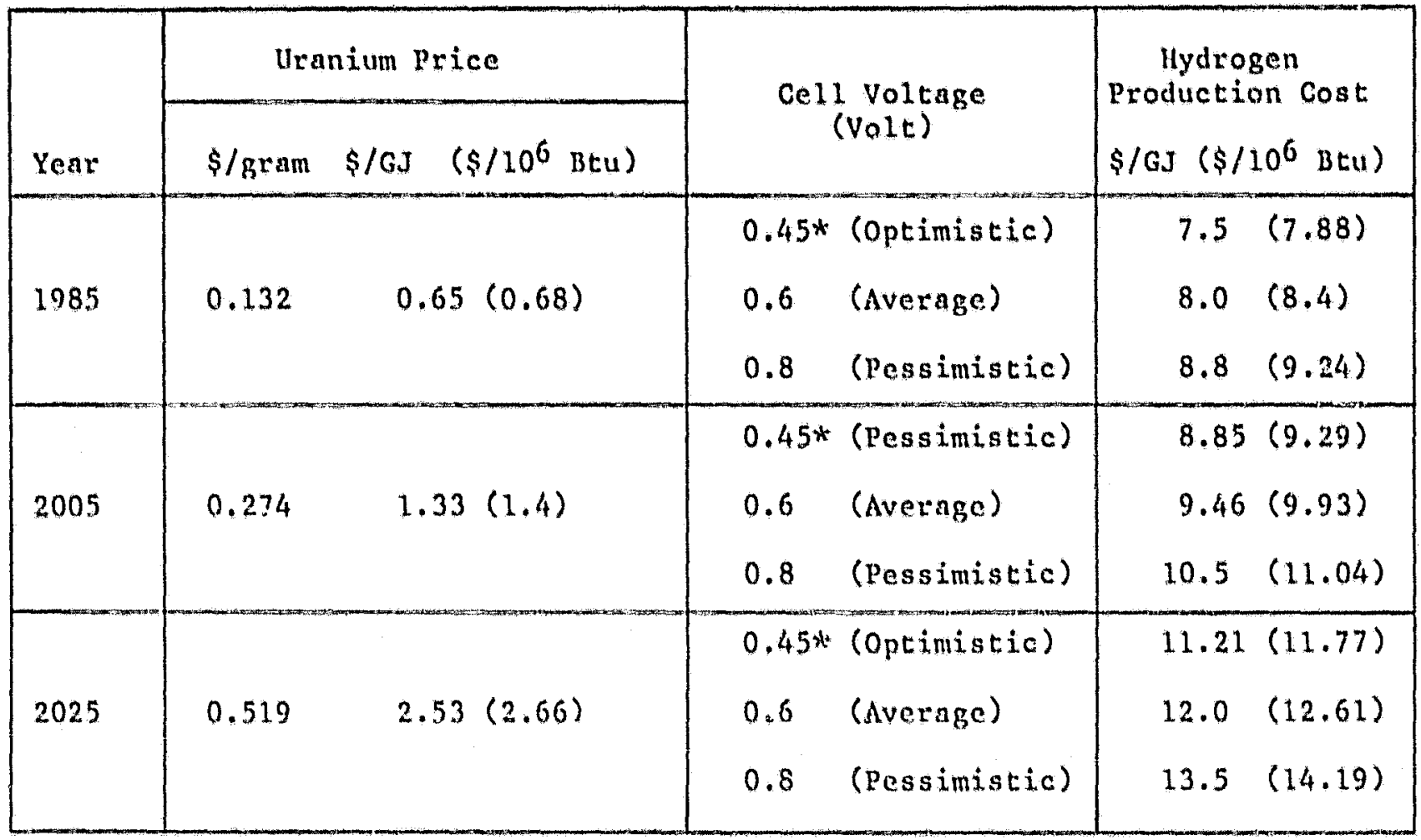

*0.45 cell voltage is not practical with the technical current density.

process Assumed: Hybrid Sulfur cycle water decomposition process using a dedicated high temperature gas-cooled reactor (HTGR)

Capacity Factor: 0.8

$\begin{array}{ll} & 0.51 \text { for } 0.45 \text { volt } \\ \text { Overall plant Efficiency } & 0.47 \text { for } 0.6 \text { volt } \\ & 0.4 \text { for } 0.8 \text { volt }\end{array}$

Plant Capacity: $\quad 10.76 \times 10^{6} \mathrm{~m}^{3} / \mathrm{day}\left(380 \times 10^{6} \mathrm{ft}^{3} / \mathrm{day}\right)$

$=130 \times 1012 \mathrm{~J} / \mathrm{day}(123.5 \times 109 \mathrm{Btu} / \mathrm{day})$

Total plan Investment

$1.277 \times 10^{9}$ dollars for 0.45 volt

(included nuclear plant)

$1.354 \times 10^{9}$ dollars for 0.6 volt

$1.452 \times 10^{9}$ dollars for 0.8 volt

Uranitum Price: IEA R D and D strategy project price assumptions for the world price of uranium 
Table 8 presents hydrogen production cost via an on-site SPE electrolyzer capable of producing $0.283 \times 10^{6} \mathrm{~m}^{3} / \mathrm{day}\left(10^{6} \mathrm{ft}^{3} / \mathrm{day}\right)$ hydrogen. Estimated hydrogen production costs in this case are based on data presented by Hittman Associates, Inc. (Reference 13). The $U$. S. electricity cost scenario for industry was used for the cost of electricity in estimating hydrogen production cost via SPE electrolyzer. The production cost of hydrogen in such a plant will be about $13.62 \$ / G J\left(14.3 \$ / 10^{6} \mathrm{Btu}\right)$ for electric cost of 30.4 $\mathrm{mi} 11 \mathrm{~s} / \mathrm{kWh}$ in the year 1985 .

Table 9 presents hydrogen production costs in a large central SPE electrolyzer using a dedicated High Temperature Gas-Cooled Reactor (HTGR). This plant is capable of producing $287 \times 10^{6} \mathrm{ft}^{3} /$ day hydrogen. Estimated hydrogen production cost in this case is based on data presented in Reference 14. IEA $R$ D and $D$ strategy project price assumptions for uranium were used in estimating hydrogen production cost via SPE electrolyzer using a dedicated HTGR. The production cost of hydrogen in such a central plant will be about 7.2 $\$ / G J\left(7.56 \$ / 10^{6}\right.$ Btu) for uranium price of $0.132 \$ / g r a m$ in the year 1985. Figures 10 and 11 present the sensitivity of hydrogen production costs to electricity and nuclear fuel costs respectively. It should be noted that hydrogen production cost presented here for a large electrolyzer using a dedicated HTGR does not include cost for required storage and transportation facilities.

\subsection{SOCIETAL ASPECTS}

Hydrogen as a fuel has very special characteristics: its prime advantages are its clean end-use and its flexibility for energy storage, transmission, and utilization; its major disadvantage is the necessity for a primary energy source, and the attendant drawbacks of that primary source. The objective of this section is to present environmental, health, and safery aspects that are encountered during the production and utilization of hydrogen. This section also summarizes many institutional and legal issues that are associated with the use of hydrogen as a fuel.

\subsubsection{ENVIRONMENTAL IMPACTS OF HYDROGEN PRODUCTION}

2.6.1.1 Hydrogen from Coal. Emissions from coal plants that produce hydrogen or any other gasification product include $\mathrm{H}_{2} \mathrm{~S}$, $\mathrm{SO}_{2}$, particulates, $\mathrm{CO}_{2}$, trace metals, toxic organic compounds, and ash. Coal and gasification facilities will utilize sulfur recovery processes which result in the release of $0.5-2 \%$ of the sulfur present in coal feed to the atmosphere as $\mathrm{SO}_{2}$. This emission is small when compared to that resulting from the direct combustion of coal.

particulate emissions could be very high, potentially, but they can be controlled by electrostatic precipitators, bag houses, venturi. scrubbexs, and other technologies. Controls on emissions of fine particulates and $\mathrm{SO}_{2}$ will also control the emissions of toxic and hazardous pollutants. However, process streams of coal technologies contain many hazardous substances whose effect on health and ecology is not known. 
Table 8. Cost of Hydrogen by the Electrolysis of Water (1978 Do11ars)

\begin{tabular}{|c|c|c|c|}
\hline \multirow{2}{*}{ Year } & \multicolumn{2}{|c|}{ Price of Industrial Electricity } & $\begin{array}{c}\text { Hydrogen Production } \\
\text { Cost }\end{array}$ \\
\cline { 2 - 3 } & $\$ / G J\left(\$ / 10^{6} \mathrm{Btu}\right)$ & mil1s/kWh & $\$ / G J\left(\$ / 10^{6} \mathrm{Btu}\right)$ \\
\hline 1985 & $8.48(8.9)$ & 30.4 & $13.62(14.3)$ \\
\hline \multirow{2}{*}{2005} & $8.95(9.4)$ & 32.1 & $14.26(14.97)$ \\
& $12.48(13.1)$ & 44.7 & $18.89(19.84)$ \\
\hline \multirow{2}{*}{2025} & $8.38(8.8)$ & 30.0 & $13.52(14.2)$ \\
& $12.67(13.3)$ & 45.4 & $19.14(20.1)$ \\
\hline
\end{tabular}

Process Assumed: G.E. Solid Polymer Electrolyte (SPE) cell

Availability Factor: 0.9

Electrolyzer Efficlency: 0.76

Plant Capactey: $0.283 \times 10^{6} \mathrm{~m}^{3} /$ day $\left(1 \times 10^{6} \mathrm{ft}^{3} /\right.$ day $)$

$$
=309.5 \times 10^{9} \mathrm{~J} / \text { day }\left(325 \times 10^{6} \mathrm{Btu} / \text { day }\right)
$$

Total Plant Investment: $632.4 \times 10^{3}$ dollars

Price of Electricity: U.S. electricity cost scenario for industries, from JPL reference scenario

Cell Voltage: 2 volts 
Table 9. Cost of Hydrogen by the Electrolysis of Water using a Dedicated HTGR

(1978 Dollars)

\begin{tabular}{|c|c|c|c|c|}
\hline \multirow[b]{2}{*}{ Year } & \multicolumn{2}{|c|}{ Urantum Price } & \multirow{2}{*}{$\begin{array}{l}\text { Cost of Electrifelty } \\
\text { from HTGR mills/kWh }\end{array}$} & \multirow{2}{*}{$\begin{array}{l}\text { Hydrogen } \\
\text { production Cost } \\
\text { \$/(GJ (\$/10 } 1 \mathrm{btu})\end{array}$} \\
\hline & \$/gram & $\$ / \mathrm{GJ}\left(\$ / 10^{6} \mathrm{BCu}\right)$ & & \\
\hline 1985 & 0,132 & $0.65(0.68)$ & 18 & $7.2(7.56)$ \\
\hline 2005 & 0.274 & $1.33(1.4)$ & 23 & $9.0(9.45)$ \\
\hline 2025 & 0.51 .9 & $2.53(2.66)$ & 31.5 & $12.19(12.8)$ \\
\hline
\end{tabular}

Process Assumed: (i. F. Solld Polymer Electrolyte (Spk) cell using a dedicated high temperature gas-cooled reactor (HTCR)

Capacity Factor: 0.8

Overall Plant Effieieney: 0.378

P.ant Capacity: $8.13 \times 10^{6} \mathrm{~m}^{3} / \mathrm{day}\left(287 \times 10^{6} \mathrm{ft}^{3} / \mathrm{day}\right)$

$=97.97 \times 10^{12} \mathrm{~J} / \mathrm{day}\left(93.3 \times 10^{9} \mathrm{Btu} / \mathrm{day}\right)$

Electrolyzar Efficiency $=0.76$ at $1000 \mathrm{PSI}$

Cell Voltage $=1.72$ volt

Capital Investment $=955 \times 10^{6}$ dollars

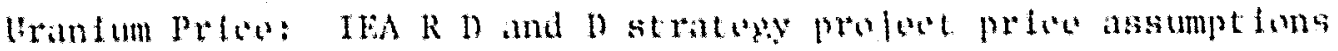
for the world priog of urimium 


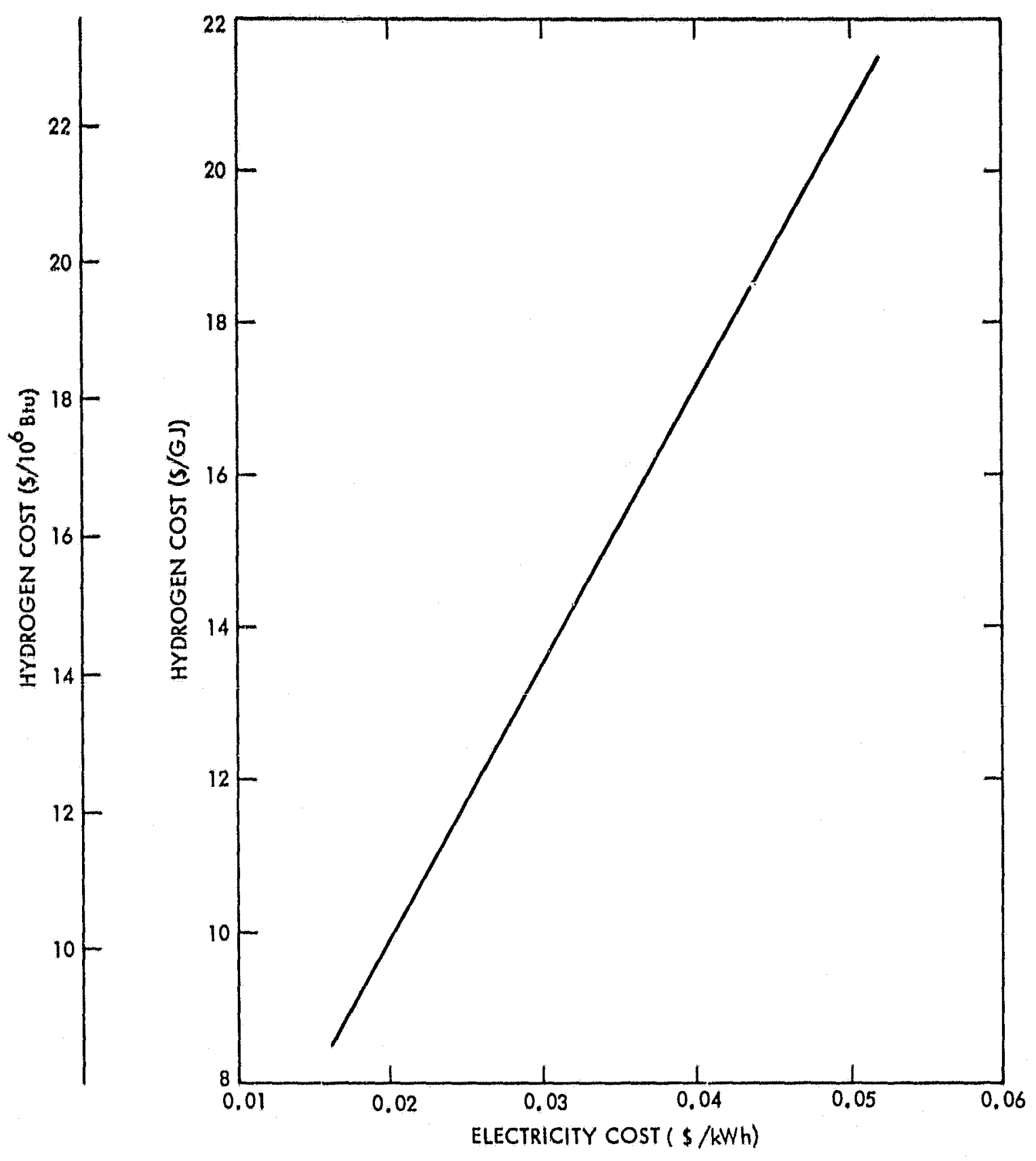

Figure 10. Sensitivity of Hydrogen Production Costs to Electricity Cost for a Small-scale SPE Electrolyzer 

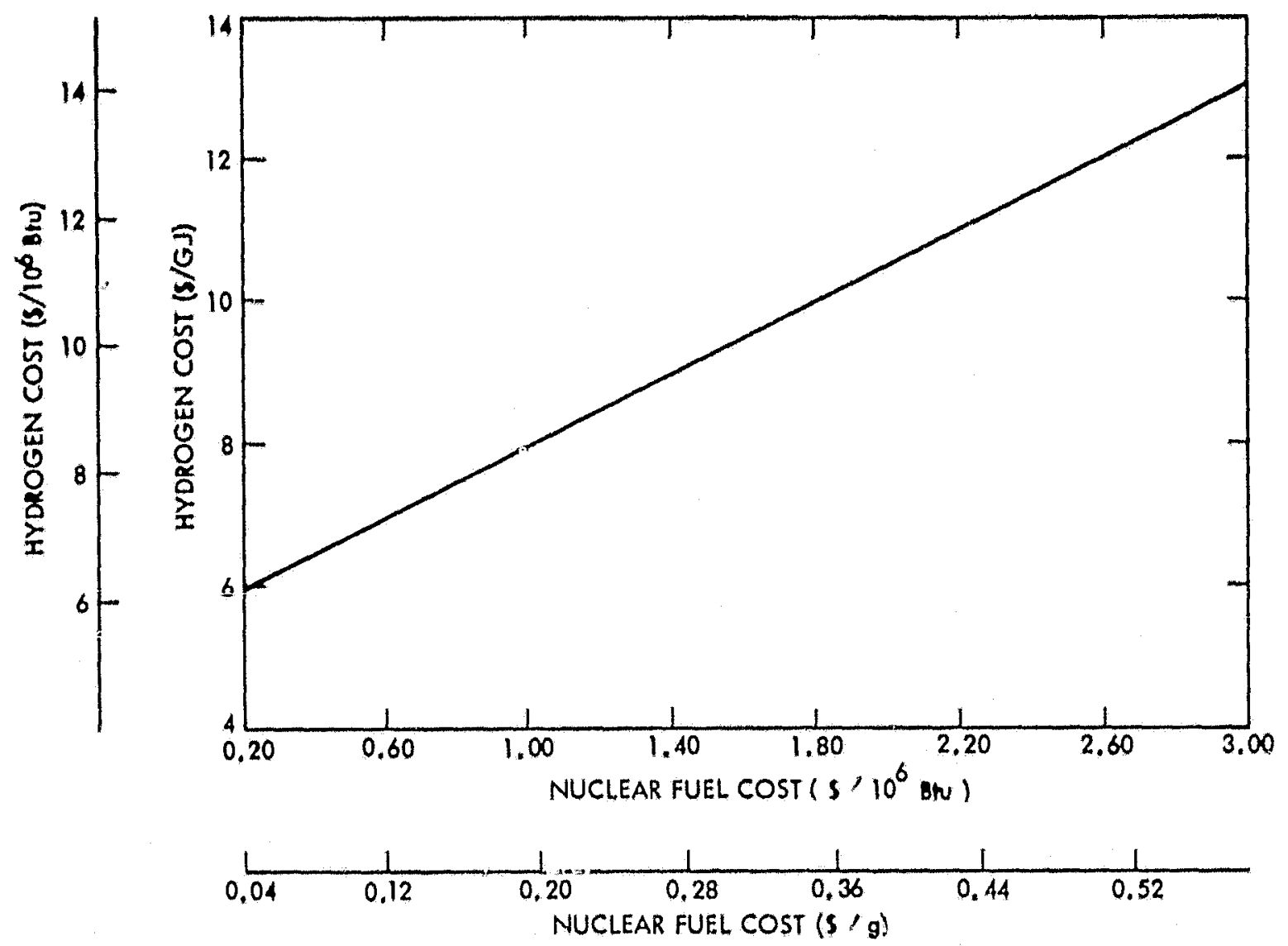

Figure 11. Sensitivity of Hydrogen Production Costs to Nuclear Fuel Cost for a Large Central SPE Electrolyzer using a Dedicated HTGR 
Casbon dioxide is a naturally-occurring pollutant. Until recently the vast quantities of $\mathrm{CO}_{2}$ generated through combustion processes have been largoly ignored. This has been the case because $\mathrm{CO}_{2}$ is not known to have any health effects at the concentrations at which it is presently found in the atmosphere. Recently, however, $\mathrm{CO}_{2}$ has been implisated in producing a warming trend by altering the "grcenhouse" effect of the atmosphere. In spite of the fact that the northern hemisphere has been experiencing a cooling trend in recent years, the southern hemisphere has apparently been warming. Additionally, it has been determined that carbon dioxide mixes across the equator so that global concentrations are relatively uniform.

A study by Paul E. Damon and Stephen K. Kunen, (Reference 15) recently assessed the variation in surface air tempera- tures during several recent solar cycles for 226 weather stations with statistical records covering 60 years or more. Their analysis concluded that meteorological data showed an incrensing warming trend of southern hemisphere cities especially below $45^{\circ}$ south. Damon and Kunen showed through their data analysis that there appear to be areas of the earth that are experiencing cooling, such as large areas of the northern hemisphere, counter-balanced by warming trends in the south. They concluded that human activity may have significantly contributed to the trend in global surface air temperatures. They feel that because of the rapid diffusion of $\mathrm{CO}_{2}$ molecules in the atmosphere, the earth wili be subject to a waying trend due to the atmospheric greenhouse effect as the $\mathrm{CO}_{2}$ concentration builds up. They explained the cooling rend in the northern hemisphere as a possible effect of increased particulate matter which has increased the albedo thereby lowering air temperatures. The diffusion of particles across the equator is not significant so that this could explain the lack of a counterbalancing cooling trend in the southern hemisphere. The nature of the $\mathrm{CO}_{2}$ problem is far from understood. It appears, however, that $\mathrm{CO}_{2}$ levels have been increasing and will continue to rise on a global scale. Because $\mathrm{CO}_{2}$ does affect the radiation balance of the earth, there is reason for concern since this is one environmental question which could pose a limit to life on earth. should a pronounced warming trend develop world-wide, the implications on plant growth, animal life, and on the climate itself could be profound. Carried to the extreme, a significant warming trend could result in melting the polar caps to such an extent that the sea level would rise and portions of continents would be flooded. Melting of the polar caps even to a slight degree, could result in clitivatic problems presently unanticipated.

Aqqueous wastes from coal gasification and gas processing units pose a potential threat to water quality. However, announced plans For the commercial production of SNG from coal (Lurgi technology) indicate designs for zero water discharge facilities. Maximum recycling of process water is planned for these plants. Contaminated process water is to be largely evaporated, with the residual water being "sed for wetting gasifier ash. Aqueous wastes will come primarily $1 . \mathrm{m}$ tar oil/water separators, steam stripper separators, gas purification systems, fuel gas desulfurization units, claus sulfur plant gas treaters, sour water strippers, and cooling tower and power plant blowdown. Potential pollutants are toxic 
elements (e.g., chromium, vanadium, and mercury), cresylic and naphthenic acids, cyanides, thiosulfates, a variety of other sulfur and nitrogen compounds, and nitrates. A potential source of surface water pollution, despite a stated design goal of obtaining zero discharge of aqueous wastes, will be from both the concentrated aqueous effluent discarded with the gasifier ash and from the leaching of this ash if it is stored on the surface of the ground. Similarly, the contamination of aquifers from surface sources is potential.ly possible because of leaching from gasifier coal ash. A recent case study of a Lurgi-process Stearns Rogers gasification plant for the E1 Paso Natural Gas Company indicated that a total of 466,700 pound/hour cf wet ash would be produced and disposed of (Reference 16). A portion of this wet ash on the order of 0.001 or $0.002 \%$ would comprise trace metals such as chromium, copper, manganese, nickel, and zine. Thus, for each plant with characteristics similar to those of this case study plant, from 40,000 to 80,000 pounds of metals would be emplaced in the ground each year. The alternative to lagooning or "land burial" is deepwell waste injection. This disposal method can be relatively costly and is subject, currently, to a considerable amount of skepticism from environmental interest groups.

Coal gasification generates about 5000 tons of ash per $10^{12}$ Btu of coal used. Ash contains both trace elements and heavy metals.

The removal of pollutants to provide a good quality environment is costly and land-intensive. However, constraints on the siting of coal conversion facilities are expected to be significant only for large facilities in either non-attainment areas or class 1 significant deterioration areas. The most realistic threat would stem From noncatastrophic types of environmental constraints. Each toxic or otlinrwise hazardous material generated by the use of coal can likely be controlled ultimately in a technical sense. However, the scale of accumulation of a wide variety of less toxic wastes will eventually impose a severe strain on the other resources. Furthermore, much of the effect will be in rural areas, so that most of the population may not be easily convinced of the total cost being incurred until severe problems, such as contamination of extensive agricultural land or ground-water resource, or the cumulative effect of water consumption reaches disastrous levels.

2.6.1.2 Hydrogen from Water by Electrolysis and Thermochemica1 Splitting using Nuclear Energy as a Primary Source of Energy. Large quantities of nuclear power and process heat are used in producing hydrogen, from water; therefore, the negative aspects of nuclear power plants apply here. The environmental issues associated with nuclear power involve the entire nuclear fuel cycle from the mining and milling of ore through the enrichment, use, and recycling of spent fuel; the transportation of fuels; and the long-term storage of nuclear wastes.

The normal radiation emissions that occur during the transportation, processing, and power generation phases of the nuclear 
cycle are extremely low and have not been as much an issue as the potential consequences of various accidents, acts of sabotage, or use of byproduct plutonium to create a halth risk or nuclear weapons.

The issue of storage of nuclear wastes revolves around their extremely long radioactive "half-lives". Such materials must be stored securely for hundreds of years.

The High Temperature Gas-Cooled Reactor (HTGR) is considered to be very safe compared to the conventional nuclear reactor. Gas-cooled reactors have an inherent advantage over liquid-cooled ones in this respect, for, a sudden 1088 of pressure would allow the liquid to vaporize rapidly, and the cooling capacity would be reduced catastrophically. The HTGR's reactivity decreases uniformly as the temperature rises, and even if there were to be a loss of coolant, because the fuel asd moderator are intimately bonded together, there could not be a major meltdown (Reference 15).

\subsubsection{ENVIRONMENTAL IMPACTS OF UTILIZING HYDROGEN AS A FUEL}

Air pollution from the combustion of fossil fuel is a growing public health hazard in the majority of urban areas in the United states. Existing strategies for improving and maintaining the air quality in urban areas are very expensive atutân, in many cases, not only have they not accomplished the expected results, they have created new problems. Therefore, clean combustible fuels will gain in importance with the growing energy demand in the urban areas of the United States. Hydrogen is an excellent energy carrier where pollution is a serious problem.

One of the major environmental problems is acid rain, Burning large amounts of foss 1 fuels in industrial countries hes increased the concentration of sulfur dioxide and sulfates in the atmosphere. These pollutants contribute to the acidity of rainfall in Northern Europe, northeast of the United States, and in Canada. Acid rain degrades health and water quality and affects specific life forms. Acid rains harm crops, fish, and timber, and also damage building materials, outside stone and concrete work, and some metallic equipment. Because hydrogen doesn't contain sulfur, it would not produce acid rain.

The main components of air pollution arising from the use of fossil fuels include sulfur oxides, nitrogen oxides, carbon monoxide, hydro-carbons, and particulates. The products of hydrogen combustion, on the other hand, are mainly water and nitrogen oxides. Today, catalytic burners enable an almost complete prevention of emission of nitrogen oxides. Also, utilizing hydrogen in a fuel cell does not produce any emissions except water vapor, and hydrogen combustion will not produce carbon dioxide which, as was mentioned before, would lead to the so called "greenhouse" effect. 
Hydrogen, of course, is one of the most flammable and explosive fuels available to us and it must be handled with appropriate respect and safeguards. An evaluation of the safety hazards of any fuel is a highly complex task that requires an interpretation of specific technical data and intercomparisons with other fuels. Fire and explosion hazards must be assessed carefully to determine the relative safety of a fuel in each potential application. Therefore, hydrogen can be safer than conventional fuels in some applications and more hazardous in other applications. The safety aspects of hydrogen have been systematically examined and compared with those of methane and gesoline; these are summarized below.

Liquid hydrogen is more difficult to contain than either liquid methane or gasoline and gasoline vapors are more difficult to contain than gaseous hydrogen or methane. Industry has proven that all three fuels can be safely and easily contained in both gaseous and liquid phases (Roference 16):

In the event of a fuel spill, a fire hazard can be expected to develop most rapidly with hydrogen, methane, and gasoline, respectively, and the fire hazard should persist in the inverse order. For a specified liquid spillage volume and ensuing fire, gasoline fires can be expected to last the longest and hydrogen fires to be the shortest lived, while all three fuels burn at nearly the same flame temperature. The scene of a hydrogen fire may be hotter $(1.3-1.8 x)$ than that of a hydrocarbon fire, but the hydrocarbon Fires will endure from five to ten times longer than hydrogen fires. (For spillage of identical liquid fuel volumes see Reference 16.)

All three fuels are ensily ignited by weak ignition sources such as those provided by matches. Even a weak spark generated by the discharge of static electricity from a human body may be sufficient to ignite any of these fuels in the air. Hydrogen is more readily ignitable than either of the hydrocarbon fuels which, however, appear to be equally susceptible to ignition.

Hydrogen fires are more difficult to detect than methane or gasoline fires, but modern detection equipment makes it possible to detect quickly and reliably the flames of all three of these fuels. Water may be used to fight fires of all three fuels, and commercial dry chemicals and high-expansion foams can be used to extinguish liquefied natural gas and gasoline fires.

The potential damage from smoke inhalation is judged to be most severe in gasoline and to decrease for methane and hydrogen fires in that order.

The wider flamable and detonable limits of hydrogen coupled with its rapid burning velocity tend to make hydrogen a greater explosive threat than methane or gasoline. Unconfined fuel-air explosions are not normally very destructive; however, confined fuel-air explosions can be devastating and hydrogen presents the greatest confined-explosion threat of the three fuels, 
For equivalent energy or volume storage, hydrogen has the least theoretical explosive potential of the three fuels considered-even though it has the highest heat of combustion (and explosive potential) on a mass basis.

Hydrogen, currently, is being stored safely and used in industry in both compressed-gas and liquid forms, and it is anticipated that metal hydride storage will be equally safe. Of the three fuels examined, zasoline is the easiest and perhaps the safest fuel to store because of its lower volatility and narrower flammable and detonable limits.

A consideration of future hydrogen applications reveals no safety problems in the industrial and commercial markets. Hydrogen safety problems may exist, however, in the transportation and residential fuel markets and additional safety analyses are needed in these areas. Lower risk (or lower cost) fuels will most likely be used to satisfy many of these markets over the next few decades; however, hydrogen should not currently be considered unsafe and cannot be excluded from consideration in any of these applications on the grounds of safety. It is believed that fuel availability and cost will outweigh fuel safety in the selection of fuels in the future, and hydrogen must be considered a contender in the fuel market.

Regulations, standards, and guidelines already exist for the storage and transportation of hydrogen.

\subsubsection{LEGAL AND INSTITUTIONAL ISSUES OF HỸ̄EROGEN ENERGY}

Horizontally and vertically integrated "energy companies" have the capital necessary for major investments in production facilities. An incentive for them to invest in these at present is not clear. Anti-trust sentiments may hinder the private-sector ficom entering the market; however, government acceptance of "natura1 monopolies" could promote private-sector entry. More likely ventures are those of joint private-public sector (federated) ventures, as in the case of nuclear energy. If hydrogen development is viewed as being in the public interest, government support of R\&D could promote its implementation. If hydrogen is seen as competing with the vested interests of energy companies, however, private sector cooperation might be diminished.

Regulatory conflicts between federal and state governments are likely in the event of a large-scale commitment to hydrogen. These conflicts can be expected to involve issues of occupational safety and health, construction regulations, licensing and professional requirements of workers, land condemnation and compensation (for production plants and pipelines), and accident liability. Federal preemption in these areas is likely to be resisted; at present, the absence of a clear resolution of these issues is a barrier. Regulation of utilities (siting, rate structures, capital investments) could involve similar federal/state regulatory conflicts. 
Because hydrogen may be produced through the use of existing technological systems, potential regulatory disputes could well be resolved prior to large-scale hydrogen implementation. For example, if nuclear power is to be used to produce hydrogen, it is possible that siting controversies could be anticipated and resolved by existing regulatory mechanisms. However, proposals for off-shore nuclear-hydrogen plants (to use available sea water) might raise unresolvable issues relating to the evolving international law-of-the-sea.

Unfamiliarity with hydrogen systems presents the problem of inadequate information for preparation of environmental impact assessments. Resource allocation issues (pertaining to water in particular) are likely to accompany the implementation of large-scale hydrogen production.

Flexibility in energy systems is desirable in many aspects. Multiple sources are to be preferred over reliance on a few systems from the point of view of overall system reliability. Hydrogen could increase flexibility.

\section{3.}

\section{CONCLUSIONS}

Today, hydrogen is used in many important industrial processes in the United States including those of refining petroleum, manufacturing ammonia and methanol, hydrogenating vegetable oils, synthesizing chemicals, manufacturing semiconductors, and for general metallurgical purposes. Current U.S. hydrogen requirements are about $1.05 \times 10^{18} \mathrm{~J} /$ year $\left(1.0 \times 10^{15} \mathrm{Btu} /\right.$ year $)$. In addition to these existing and traditional markets, hydrogen conceivably could be used in energy sectors of the United States in either a direct or indirect form. The proposed direct form of hydrogen usage will be in transportation, as a natural gas supplement, and in fuel cell sectors. The indirect use of hydrogen in the energy sector of the United states includes its use in the refinery and synfuel industry. An assessment of the potential role of hydrogen has to take into account that the substitution of conventional energy carriers by hydrogen must be competitive, and that, in addition to the full development of techniques for hydrogen application, a hydrogen infrastructure must evolve.

In view of the expected shortages of natural gas and oil in the United States, the production of hydrogen from this source will be phased out in the future. In this event, future demands will probably be met with hydrogen that is produced from coal and water by both electrochemical and thermochemical methods. Mature technologies are available for producing hydrogen from coal on a commercial scale, and technologies are under development for obtaining hydrogen from water by the thermochemical splitting of water and by advanced electrolysis. Coal gasification can provide the additional hydrogen needed to meet near- and mid-term demands. The long-term energy demands, however, may have to be met by hydrogen that is obtained from water because the environmental hazards associated with the increased use of coal may lead to restrictions on coal production sind utilization, and because coal will also become depleted. 
The cost of hydrogen production through various methods is given in Tables 5, 7 , and 9 (see Section 2.5). The projected cost of producing hydrogen from coal for the year 1985 is about $5.25 \$ / G J$ $\left(5.51 \$ / 10^{6} \mathrm{Btu}\right)$ as compared to about $\$ 7.5-8.0 / \mathrm{GJ}\left(\$ 7.88-8.4 / 10^{6}\right.$ Btu) for hydrogen from thermochemical water decomposition and about $\$ 7.2 / \mathrm{GJ}\left(\$ 7.56 / 10^{6} \mathrm{Btu}\right)$ for hydrogen from electrolysis using a dedicated HTGR with the cost spread being a function of both energy costs and technology maturity. Coal gasification is a mature technology in which future improvements are not likely to have a significant impact on economics. In other cases, technologies are only in developmental stages and therefore provide more potential for a future reduction in costs. The cost data presented in this report indicate that, in the United States, the production of hydrogen from coal would be cheaper than its production from thermochemical and electrolysis processes. The cost of production using thermochemical or electrolysis processes and a dedicated HTGR would be about the same (for the period studied). However, the cost of producing hydrogen is more sensitive to the nuclear fuel cost when using the electrolysis process than it is when using the thermochemical process.

It should be noted that even though the cost of producing hydrogen through small-scale electrolysis is greater than that of the other processes examined here, this process has an advantage in being economically scalable to smaller sizes than would be practical for the coal gasification, thermochemical, or large electrolyzer methods using a dedicated HTGR. In general, over the next 45 years large scale hydrogen production in the United States can be expected to shift from natural gas and petroleum toward coal. Then at the end of this interim period hydrogen production is likely to shift toward a nuclear energy base mainly due to environmental and social constraints associated with increased coal utilization. In addition, hydrogen production by small-scale electrolysis would contribute to some extent during this period mainly due to economically scalable reduced size for small users of hydrogen and therefore eliminating cost and complexity associated with hyrogen storage, transportaion, and distribution.

The potential use of hydrogen in the United States can thus be assessed in some of the following ways.

\section{HYDROGEN IN PETROLEUM REFINING}

The demand for hydrogen in the United states refining industry is expected to increase substantially because of accelerated hydrotreating requirements. The factors causing this increased requirement include: the rapidly rising demand for gas oil, distillate, and atmospheric residual oil, the increased use of sour crude, and tighter regulations pertaining to sulfur oxide emissions. 
The demand for hydrogen in the U.S. ammonia industry is not expected to rise significantly in the near future. Nearly all of the U.S. capacity is based on plants with integrated methane reforming and ammonia synthesis capabilities. Factors that affect demand in this market include: a substantial excess plant capacity in the United states, rising costs and falling prices, and the prospect of major imports of ammonia to the United States from abroad.

The demand for hydrogen in the United States for methanol production could become very significant in the future, especially if methanol becomes an inportant element of the basic U.S. fuel supply. In the chemical industry, the demand for methanol has been rising faster than the overall U.S. economic growth. Factors that affect this demand include a high demand for formaldehyde by the housing and construction industries and the introduction of key methanol derivatives into several chemical markets.

\section{HYDROGEN FOR SYNFUEL MANUFACTURING}

To the extent that the United States limits the importation of foreign petroleum and places a large dependence on synfuel obtained mainly from domestic resources such as coal and oil. shale, the demand for hydrogen prnduction to synthesize synfuel will be increased. This increase will be a significant factor in stimulating the development of the hydrogen market in the synfuel sector in the United States.

\section{HYDROGEN AS AN ENERGY CARRIER}

Hydrogen can be used in a mixture with natural gas as in heating fuel and can be used in the transportation sector (mainly in aviation) and as a fuel for fuel cells. A significant demand for hydrogen as an energy carrier could be realized, provided that hydrogen is able to compete economically with other energy carriers. The commercialization of efficient and cheap fuel cells is essential in "eveloping a hydrogen market in the fuel cell sector. Institutional and infrastructure barriers have to be resolved if hydrogen is to play a role as an aviation fuel. 
Albedo:

Atmospheric resid:

DAO:

DCFRR:

Distillate fuels:

Gas oil:

HTGR:

HYCSOS :

OTEC :

Sour crude:

Thermal naphtha:
The fraction of incident light or electromagnetic radiation that is reflected by the surface of the earth.

A liquid product obtained as residue from the atmospheric distillation of petroleum.

Deasphalted $0 i 1$.

Discounted Cash Flow Rate of Return.

Distillate fuels are petroleum stocks that boil in the range of $177^{\circ} \mathrm{C}$ to $371^{\circ} \mathrm{C}$ and have flash points of $49^{\circ} \mathrm{C}$ or higher. They include kerosene, heating oils (No. 1 and No. 2 fue 1 oils) and diesel fuels.

A liquid petroleum distillate with viscosity and boiling range between kerosene and lubricating oil. Boiling range between $232^{\circ} \mathrm{C}\left(450^{\circ} \mathrm{F}\right)$ and $427^{\circ} \mathrm{C}\left(800^{\circ} \mathrm{F}\right)$. Flash point $66^{\circ} \mathrm{C}\left(150^{\circ} \mathrm{F}\right)$. Autoignition temperature $338^{\circ} \mathrm{C}\left(640^{\circ} \mathrm{F}\right)$. Uses: absorption oil; manufacture of ethylene.

High Temperature Gas-cooled Reactor.

It is a chemical heat pump which utilizes the heat of adsorption/desorption of hydrogen in a metal alloy for the storage and recovery of thermal energy for heating and cooling. The acronym HYCSOS refers to a hydride conversion and storage system.

Ocean Thermal Energy Conversion.

High-sulfur crude oils are called "sour" particularly if the sulfur is corrosive, and low-sulfur crude oils are called "sweet". There is no particular sulfur level which is recognized as a dividing line.

This is naphtha produced through visbreaking, decoking and hydro-cracking processes. 


\section{REFERENCES}

1. Cobb, Calvin B., Energy and Hydrogen in the United States Refining Industry, paper presented in the Workshop on Supply and Demand of Hydrogen as Chemical Feedstock, Dec. 12-14, 1977.

2. Amos, W. J., et al., A Study of Industrial Hydrogen and Syngas Supply System, draft Final report, Air Products and Chemicals, Inc., Oct. 1979.

3. Levy, A. H., Hydrogen for Fuel Cell3, paper presented in the Workshop on Supply and Demand For Hydrogen as Chemical Feedstock, Dec. 12-14, 1977.

4. Kelley, J. H., and Laumann, E. A., "Hydrogen Tomorrow - Demands and Technology Requirements," Report 5040-1, Jet Propulsion Laboratory, Pasadena, Calif., March 1976.

5. Earbman, G. H., Krasiuki, B. R., Hardman, C. C., Lin, S. S. and Parker, G. H., Economic Comparison of Kydrogen Production Using Sulfuric Acid Electrolysis and Sulfur Cycle Water: Decomposition, Westinghouse Electric Corporation, prepared for EPRI, EM-789, Research Project 1082-6, June 1978.

6. Russe11, J. H., and Nuttal1, L. J., Development Status of Solid Polymer Electrolyte Water Ekectrolys is for Large Scale Hydrogen Generator. General Electric Company, Proceeding of the DOE Chemical/Hydrogen Energy System Contractor Review, Nov. 27-30, 1978 Washington, D.C., Published May 1979.

7. Michaels, H. J. "Hydrogen Production Via K-T Gasification Process: Current Economic and Technological Aspects," paper presented in symposium for hydrogen. for energy distribution, sponsored by Institute of Gas Technology, July 24-28, 1978.

8. Hagler, R., "NASA Experience with Gaseous Hydrogen," JPL Internal Docutient 5030-187, Jet Propulsion Laboratory, Pasadena, Calif., March 1, 1978.

9. Tatche11, J. A., "Hydrogen in the Chemical Industry," Imperial Chemical Industries, Ltd., November 1976.

10. "Hydrogen Progress: Hydrogen Homestead," Billings Energy Corporation brochure, Provo, Utah, Fali Quarter 1977.

11. Buchner, H., and Saufferer, H., "Results of Hydride Research and the Consequences for the Development of Hydride Vehicles," 4 th Symposium on Low Pollution Power systems Development, CCMS, NATO Washington, D.C. April 1977.

12. Telephone Communication with Mr. Robert K. Fujita, Manager, Technical Liaison for Pacific Resource Inc. (Parent of GASCO), May 16, 1980. 
13. Scherkenback, W. W., Dohrman, D. R., Economics and Market Potential of Hydrogen Production, Hittman Associates, Inc., proceedings of the DOE Chemical/Hydrogen Energy System Contractor Review, Nov. 27-30, 1978 Washington, D.C., Published May 1979.

14. Foh, S. E., Escher, W. J., Donakowski, T. D., Dedicated Nuclear Facilities for Electrolytic Hydrogen Production, paper presented in symposium for hydrogen for energy distribution, sponsored by Institute of Gas Technology, July 24-28, 1978.

15. Damon, P. E. and Kunen, S. M., Global Cooling, Science, Vol. 193, No. 4252, P. $447,1976$.

16. Uniter States Environmental Protection Agency, Evaluation of pollution Control in Fossil Fuel Conversion Processes, EPA-650/2-74-009-C.

17. Royal Commission on Environmental Pollution, sixth report, Nuclear Power and the Environment, september 1976.

18. Hord, J., "How Safe is Hydrogen?", paper presented in Symposium for hydrogen for energy distribution, sponsored by Institute of Gas Technology, July 24-28, 1978. 